\author{
Z.A. DURIAGINA ${ }^{1,2}$, V.V. KULYK ${ }^{1, *}$, O.S. FILIMONOV ${ }^{1, * *}$, \\ A.M. TROSTIANCHYN ${ }^{\text {, }}$, and N.B. SOKULSKA ${ }^{3}$ \\ ' Lviv Polytechnic National University, \\ 12 Stepan Bandera Str., UA-79013 Lviv, Ukraine \\ 2 The John Paul II Catholic University of Lublin, \\ 14 Al. Racławickie, PL-20950 Lublin, Poland \\ ${ }^{3}$ Hetman Petro Sahaidachnyi National Army Academy, \\ 32 Heroes of Maidan Str., UA-79012 Lviv, Ukraine
}

*kulykvolodymyrvolodymyrovych@gmail.com, **filimonov.alexey.97@gmail.com

\title{
THE ROLE OF STRESS-STRAIN STATE OF GAS TURBINE ENGINE METAL PARTS IN PREDICTING THEIR SAFE LIFE
}

The influence of various factors on the workability of critical metallic parts of a gas turbine engine (GTE) is analysed and systematized. As shown, compressor blades fail as a result of foreign-objects' damage, gas corrosion, and erosion. Compressor blade roots in most cases fail due to fretting wear caused by vibrations, while the fir-tree rim of turbine discs fails due to low-cycle fatigue (LCF) damage and creep. An increase in the radial gaps between the rotor and stator of the turbine reduces the thrust force and causes changes in the gas-dynamic loading of the engine components. Additional oxidation of metal parts is observed under the action of hot gases from the combustion chamber. The principles of material selection for manufacturing turbine blades and disks, concepts of alloying heat-resistant alloys, and modern methods of surface engineering due to applying protective oxidation-resistant coatings, in particular, chemical vapour deposition (CDV), physical vapour deposition (PVD), air plasma spraying (APS), etc., are also described. To predict the lifetime of turbine disks, it is proposed to use the modified Walker model and the Miner's rule. To specify the time before failure of metal blades of the turbine, it is proposed to use the finite element method. To monitor the working-surfaces' deformations of the gas turbine engine, it is recommended to use optical-digital methods.

Keywords: gas turbine materials, fatigue, durability, damageability, coatings, finite element method.

Citation: Z.A. Duriagina, V.V. Kulyk, O.S. Filimonov, A.M. Trostianchyn, and N.B. Sokulska, The Role of Stress-Strain State of Gas Turbine Engine Metal Parts in Predicting Their Safe Life, Progress in Physics of Metals, 22, No. 4: 643-677 (2021) 


\section{Introduction}

Gas turbine engines (GTE) are widely used in energetics, aviation, shipbuilding and mechanical engineering. Improving the performance of the GTE is possible as a result of design decisions, improvement of operating modes and optimal choice of materials with high specific strength, thermal stability, oxidation resistance and heat resistance. An important aspect of trouble-free operation of GTE is the development of effective means of predicting their safe lifetime [1]. The main reasons for failure of the GTE blades are low-cycle fatigue, the development of creep, the action of vibrations and centrifugal forces, gas corrosion, erosion, cavitation, etc. To ensure reliable operation of the GTE turbine blades, their average operating temperature should not exceed $900-1000{ }^{\circ} \mathrm{C}$, and the maximum (short-term allowable) one should not exceed $1100{ }^{\circ} \mathrm{C}$. Recently, the maximum allowable gas temperature at the inlet to the turbine of aircraft engines is increasing, which is achieved by increasing the efficiency of air cooling. An important role is played by the correct choice of material, composition of protective coatings, and technology of manufacturing engine parts, which ensures the stability of corrosion and mechanical properties [2-6].

The characteristics of the operating environment (composition, temperature, pressure) have a significant impact on the lifetime of components and units of aviation GTE. It is also important to in-situ monitor the processes of the microstructure degradation and, accordingly, deterioration of the properties of the material [7]. At low temperatures, the operating conditions of engines in transient modes deteriorate. As a result of sudden hydrodynamic loading during start-up, the loss of gasdynamic stability of the compressor and excessive increase of temperature and pressure of turbine gases are possible [8].

It is expedient and promising to use non-destructive methods to monitor the technical condition of engine components. Therefore, it is important to analyse the existing approaches and methods of analysis of the efficiency of GTE components and assess the possibility of their harmonization taking into account the dynamics of microstructure degradation, phase composition and changes in the defect hierarchy of structural materials.

\section{Influence of Operation Conditions on Functioning the Gas Turbine Engine}

The most characteristic damage to gas turbine engines during long-term operation is erosion of the components of the flowing part and the increase of radial gaps. In practice, this effect is manifested in the initial period of operation, mainly due to intensive wear of the seals of the flowing part during operation in different modes (due to the 
contacts of the peripheral part of the blades with seals) [9]. The magnitude of the radial gap between the rotor and the stator depends on many factors:

- manufacturing accuracy;

- magnitude and rate of thermal deformation of engine components;

- rotational speed of the rotor;

- wear of engine components.

It should be noted that the values of the radial gaps should not be less than the allowable norm, as this can lead to failure of the blades or to intensive wear of the contacting parts. The air-gas mixture flowing through the radial gaps does not perform useful work. Therefore, the losses of mechanical energy in the gas generator increase, which leads to the deviation of the operating process parameters from the optimal values. As a result, the thrust force decreases and the specific fuel consumption increases, as well as the gas-dynamic loads on the engine components increase, which directly limits its lifetime [9].

Given the substantial requirements for operational safety in modern aviation, the system of assigning the differential lifetime of the GTE was adopted [10]. Differential lifetime may be different for the most responsible engine components, depending on the actual reserves of performance under certain operating conditions. Such components include parts of the compressor, gas turbine, main combustion chamber, engine power components, etc. Given the modular design of the GTE, this method allows the full use of the resource capabilities of parts and components. In this case, the workability condition of the main units of the engine can be formulated as follows [10]: the operating stresses in the structural components should not exceed the allowable stresses, i.e.,

$$
\sigma \leq[\sigma]
$$

where $\sigma$ and $[\sigma]$ are operating and allowable stresses, respectively.

For a new engine, the average values of the operating stresses $\sigma_{\mathrm{m}}$ are much lower than the allowable $\left[\sigma_{\mathrm{m}}\right]$, so the probability of the part failure is low. In the process of increasing the engine operating time, there is a deterioration of its thermodynamic parameters. In this case, the operating stresses $\sigma_{\mathrm{m}}$ increase, i.e. the mathematical expectation of the operating stresses is shifted to the right. At the same time, due to the accumulation of microdamages in the part, the allowable stresses are reduced, and the mathematical expectation of $\left[\sigma_{\mathrm{m}}\right]$ is shifted to the left. It follows that with increasing operating time of the engine components, its reliability decreases, and the number of failures of the power unit in flight and early decommissioning of engines increases [10]. Analysing the literature data [11], we see that during the year there were 144 incidents with aircraft of classes 1-3 in flight due to failures and malfunctions of the GTE (Fig. 1). 


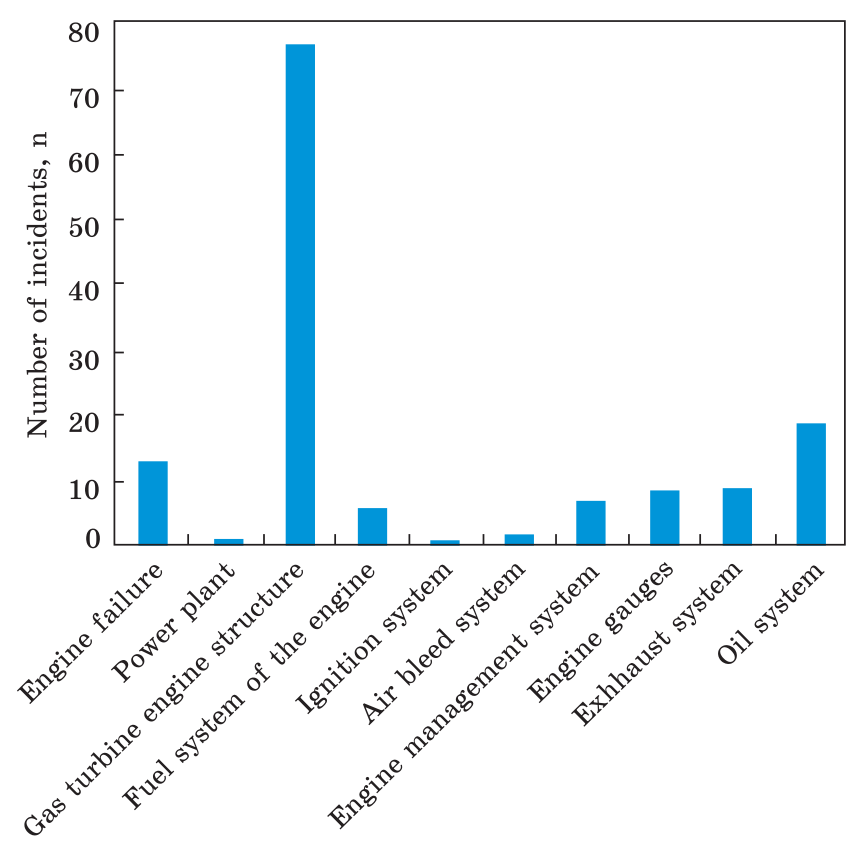

- fatigue failure of the blades;

- defects of engine rotor supports;

- failure of combustion chamber components;

- warping, melting or burning of nozzle device blades and gas turbine blades;

- exhaustion of long-term strength of gas turbine blades and disks.

Exhaustion of long-term strength of the structural material occurs as a result of creep, namely, the process of increasing the residual deformation over time under the action of constant load and elevated temperature. Creep causes failure of the GTE as a result of destruction or deformation of the blade material above the allowable limit. The rate of exhaustion of long-term strength depends on the temperature and operating stresses, the value of which is determined by the operating conditions of the engine. Estimation of the influence of operational factors on the lifetime exhaustion speed is shown on an example of the D-436-148 gas turbine engine. The method of calculating the residual life is based on the algorithm for calculating the durability of the operating blade of a high-pressure turbine (the most loaded component of the engine, which limits its lifetime). The Larsen-Miller parameter has been widely used to assess the durability of gas turbine blades. This allows predicting the lifetime of the engine material depending on time and temperature. For this purpose, a correlation approach based on the Arrhenius rate equation was used $[12,13]$ :

$$
P_{L . M .}=T \cdot\left(c+\lg t_{d}\right),
$$


where $T$ is the blade temperature, $\mathrm{K} ; c$ is the constant for heat-resistant nickel alloys, $c=20 ; t_{d}$ is the durability of the operating blade, $h$.

The temperature of the cooled blade can be determined from the ratio $[12,13]$ :

$$
\theta=\frac{T_{g}^{*}-T}{T-T_{c}^{*}},
$$

where $\theta$ is the cooling intensity factor, $T_{g}^{*}$ is the gas temperature in front of the turbine, $T$ is the blade material temperature, and $T_{c}^{*}$ is the cooling air temperature.

The value of the cooling intensity factor $\theta$ can be determined from the reference information, if the cooling method, the design features of the blades, and the volume of cooling air are known [8]. The values of the parameters required to determine the material temperature of the turbine blades were defined by thermodynamic calculation. It was found that when the ambient air temperature changes from $-30{ }^{\circ} \mathrm{C}$ to $+37^{\circ} \mathrm{C}$, the gas temperature in front of the turbine and operating stresses in the turbine blades change by $18 \%$ and $3.6 \%$, respectively. When the turbine efficiency is reduced by $4.0 \%$, the gas temperature behind the turbine will increase by about $1.4 \%$ [14].

The relative value of damage to the turbine blades was calculated by the formula:

$$
\bar{a}=\frac{a_{t a}}{a_{15}},
$$

where $a_{15}$ is damage to the blades during take-off under standard atmospheric conditions $\left(t_{a}=15{ }^{\circ} \mathrm{C}\right), a_{t a}$ is damage to the blades during take-off under real operating conditions $\left(t_{a \min }=-30{ }^{\circ} \mathrm{C}, t_{a \max }=37^{\circ} \mathrm{C}\right)$.

Analysis of the calculation results indicates a significant impact of operating conditions on the damage to the blades. Increasing the air temperature from $15{ }^{\circ} \mathrm{C}$ to $37{ }^{\circ} \mathrm{C}$ causes an increase in damage to the blades by more than 19 times. Reducing the air temperature to $-30{ }^{\circ} \mathrm{C}$ reduces the damage by about $10^{4}$ times. Depending on the operating conditions, the influence of the radial gaps in the turbine is manifested in an increase in the damage to the blades by $1.8 \ldots 6$ times. Thus, it becomes obvious the need to differentiate the lifetime of modern GTE not only by the condition of the engine components, but also by the operating conditions. To predict the residual life of passenger aircraft engines, the following information is mainly used:

- diagnostic data on the technical condition of the engine;

- total engine operating time in all modes;

- total operating time in take-off mode;

- total operating time in the maximum long-term mode;

- total number of flight cycles;

- total number of launches. 
For the D-436-148 engine, its operating times in the take-off mode and in the maximum long-term mode should not exceed $2 \%$ and $20 \%$ of the total operating time in all modes, respectively [10,14]. The calculation of the residual life of the engine by the criterion of long-term strength under operating conditions is carried out by the equation [14]:

$$
\Delta R=\tau-\tau_{f},
$$

where $\tau$ is the permissible engine operating time and $\tau_{f}$ is the actual engine operating time.

In order to increase the objectivity of the decision on the value of the residual life, the following equation is proposed [14]:

$$
\Delta R=\left(1-\sum_{i=1}^{n} a_{i}\right) \cdot k,
$$

where $a_{i}=\frac{\tau_{i}}{t_{d i}}$ is the total damage to the turbine blades, $\tau_{i}$ is the engine operating time during the i-th take-off, $\tau_{d i}$ is the durability of the operating blade during the i-th take-off, $i$ is the current number of the takeoff, $k$ is the durability margin factor.

Improving the reliability of determining the residual life of the hot part of the GTE according to the calculation equation is achieved taking into account the actual operating conditions and technical condition of the engine. To minimize the required number of controlled parameters of the GTE, the degree of influence of temperature and operating stresses on the durability of the blades in take-off mode was determined [15]. It was found that the increases in the blade temperature by $1 \%$ and in the operating stresses by $1 \%$ lead to the decreases in the durability of the blades by $39.4 \%$ and $3.7 \%$, respectively [15].

\section{Lifetime Prediction of Gas Turbine Engine Elements}

\subsection{Calculation of Turbine Disk Durability}

The main function of the turbine disk is to provide rotational motion of the shaft on which the disk is fixed, by the method of force and translational radial motion transmission of the blades installed in this disk. During the operation of a gas turbine engine, the turbine disk undergoes significant mechanical and thermal stresses due to the high rotational speed and temperature gradient [16]. Failure of the turbine disk can affect the basic function of the engine, which in most cases will have catastrophic consequences. Therefore, a detailed analysis of the reliability and durability of the turbine disk is of great importance for the GTE [17].

The rims of the disks are exposed to high cyclic stresses from centrifugal forces and thermal stresses from the flow of steam acting on the turbine blades in combination with a high concentration of stresses. 


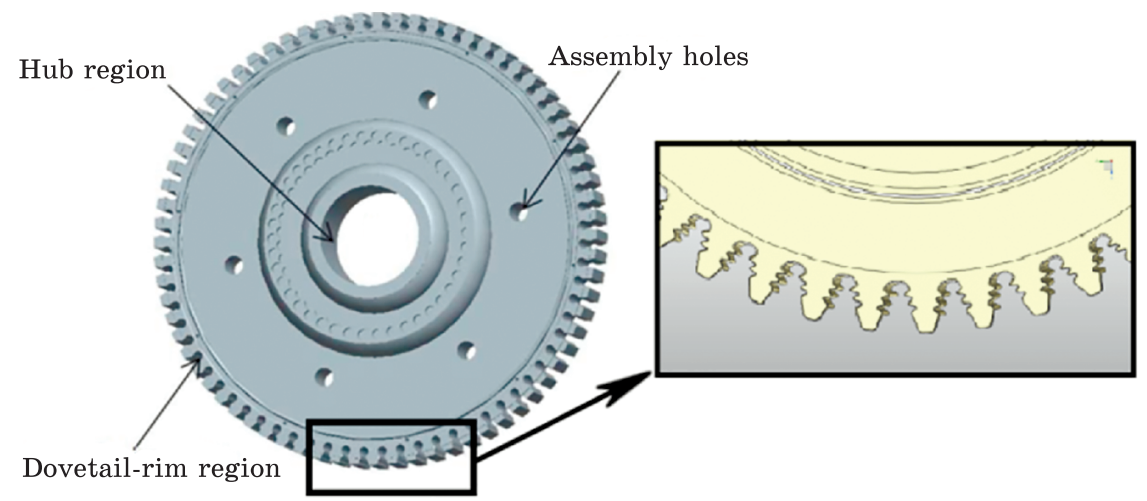

Fig. 2. The example of stress local zone of turbine disc. Reprinted with permission from Z. Lv et al., J. Mat. Sci. Tech., 29, No. 10: 4143 (2015). Copyright 2015, Springer [25]

Stresses also increase due to loose installation of the blades in the disk, when it is exposed, along with centrifugal force, to alternating stresses due to the blades oscillation [18]. The main mechanism of turbine disk damage is low-cycle fatigue (LCF) failure and creep, when the cumulative energy of cyclic deformation approaches a critical value. In this case, cracks are generated, which propagate to the failure of the part [19].

A turbine disk of the GTE has three critical stress zones (Fig. 2): the fir-tree rim (or dovetail-rim), the assembly holes, and the hub [20, 25].

In the case of using the deformation approach to estimate the fatigue life, the influence of medium stresses is taken into account [21]. There are many models for assessing fatigue life, which have their advantages and disadvantages. The Goodman prediction model [22] shows conservative results, and the Morrow model [23] in most cases overestimates fatigue life. The Smith-Watson-Topper (SWT) model [24] gives results similar to the Walker model, but with less accuracy. The modified Walker model showed the best results in predicting the lifetime of the disks under the influence of medium stresses, so special attention was paid to this method.

Zhiqiang $\operatorname{Lv}$ et al. [25] demonstrated their method for predicting turbine disk lifetime using a modified Walker model and Miner's formula. Using the finite element method, they modeled a three-dimensional model of the segment, which is $1 / 6$ part of the disk without a fir-tree structure, and 1/49 part of the turbine disk without assembly holes made of superalloy GH4133, the properties of which are shown in Table 1.

The spectrum of the rotational speed of the turbine disk for $800 \mathrm{~h}$ of operation at different operating cycles is shown in Table 2 [25].

Zhiqiang $\mathrm{Lv}$ et al. [25] found that the assembly hole in the segment of 1/6 part of the disk and the fir-tree rim region in the segment of 
1/49 part of the disk are the critical high stress region. The maximum values of stress and strain for these regions under the same operating conditions are given in Table 3.

Since the maximum stresses in the fir-tree rim region are higher, it is this area that limits the lifetime of the turbine disk, and it is advisable to perform calculations for this region [18].

Table 1. Properties of the steel GH4133. Adapted from Z. Lv, H. Huang, and H. Gao, J. Mat. Sci. Tech., 29, No. 10: 4143 (2015). Copyright 2015, Springer [25]

\begin{tabular}{|c|c|c|c|c|}
\hline $\begin{array}{c}\text { Temperature } \\
T\left({ }^{\circ} \mathrm{C}\right)\end{array}$ & $\begin{array}{c}\text { Young modulus } \\
E(\mathrm{GPa})\end{array}$ & $\begin{array}{c}\text { Poisson's ratio } \\
\mathrm{v}\end{array}$ & $\begin{array}{c}\text { Coefficient of } \\
\text { thermal expansion } \\
\left(10^{-6} /{ }^{\circ} \mathrm{C}\right)\end{array}$ & $\begin{array}{c}\text { Density } \\
\rho\left(\mathrm{kg} / \mathrm{m}^{3}\right)\end{array}$ \\
\hline 20 & 223 & 0.36 & 12.0 & \\
100 & 219 & 0.37 & 12.0 & \\
200 & 214 & 0.34 & 12.9 & \\
300 & 207 & 0.35 & 13.5 & \\
400 & 203 & 0.35 & 13.9 & \\
500 & 197 & 0.37 & 14.6 & \\
600 & 190 & 0.35 & 15.0 & \\
700 & 183 & 0.35 & 15.8 & \\
800 & 176 & 0.39 & 16.6 & \\
\hline
\end{tabular}

Table 2. Works parameters of the turbine disc under $800 \mathrm{~h}$. Adapted from Z. Lv, H. Huang, and H. Gao, J. Mat. Sci. Tech., 29, No. 10: 4143 (2015). Copyright 2015, Springer [25]

\begin{tabular}{|l|c|c|c|}
\hline \multicolumn{1}{|c|}{ Working cycles } & Number of cycles & $\begin{array}{c}\text { Rotational speed } \\
(\mathrm{rpm})\end{array}$ & Working cycles \\
\hline Low frequency cycle & 1220 & 0 & 10870 \\
Full throttle cycle & 1850 & 3360 & 10870 \\
Cruise cycle & 17320 & 9600 & 10870 \\
\hline
\end{tabular}

Table 3. Stress and strain distribution for different parts of the turbine disc. Adapted from Z. Lv, H. Huang, and H. Gao, J. Mat. Sci. Tech., 29, No. 10: 4143 (2015). Copyright 2015, Springer [25]

\begin{tabular}{|l|c|c|r|c|}
\hline \multicolumn{1}{|c|}{ Working cycles } & $\begin{array}{c}\text { Maximum } \\
\text { stress } \sigma_{\max } \\
(\mathrm{MPa})\end{array}$ & $\begin{array}{c}\text { Minimum } \\
\text { stress } \sigma_{\min } \\
(\mathrm{MPa})\end{array}$ & $\begin{array}{r}\text { Total strain range } \\
2 \varepsilon_{a}\end{array}$ & Segment \\
\hline Low frequency cycle & 704.58 & 0 & $3.5247 \mathrm{e}-003$ & $1 / 6$ \\
Full throttle cycle & 704.58 & 272.81 & $2.15 \mathrm{e}-003$ & \\
Cruise cycle & 704.58 & 572.76 & $6.595 \mathrm{e}-004$ & \\
\hline Low frequency cycle & 1011.90 & 0 & $6.0213 \mathrm{e}-003$ & $1 / 49$ \\
Full throttle cycle & 1011.90 & 362.42 & $3.8482 \mathrm{e}-003$ & \\
Cruise cycle & 1011.90 & 787.55 & $1.3348 \mathrm{e}-004$ & \\
\hline
\end{tabular}


Fig. 3. General view of the regressed inverse hyperbolic tangent curve. Reprinted with permission from Z. Lv et al., J. Mat. Sci. Tech., 29, No. 10: 4143 (2015). Copyright 2015, Springer [25]

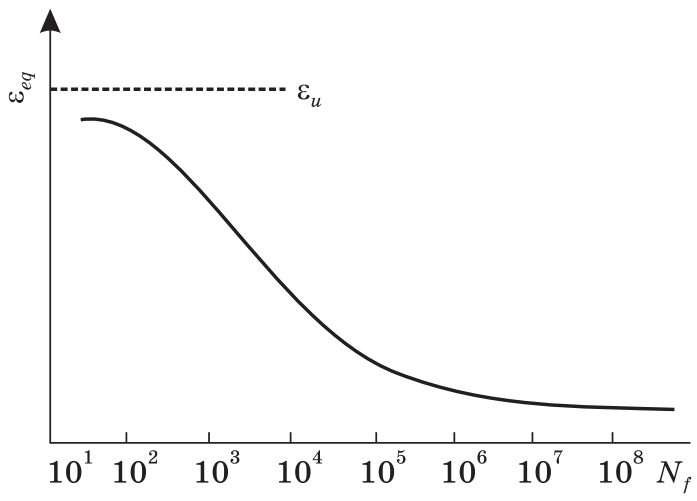

The Walker model determines the equivalent local deformation $\varepsilon_{e q}$ [26]:

$$
\varepsilon_{e q}=\left(2 \varepsilon_{a}\right)^{m}\left(\sigma_{\max } / E\right)^{1-m},
$$

where $\varepsilon_{a}$ is the amplitude of local deformation, $m$ is the material constant, for GH4133, $m=0.55, \sigma_{\max }$ is the maximum nominal stress, and $E$ is Young's modulus.

Since in the range of $10^{3}-10^{6}$ cycles the tendency of regressive inverse hyperbolic tangent curve is relatively simple (Fig. 3), Zhiqiang Lv et al. [25] used a more concise functional form to fit experimental data into this range. The experimental data of the local deformation amplitude $\left(\varepsilon_{a}\right)$, maximum nominal stress $\left(\sigma_{\max }\right)$ and number of cycles to failure $\left(N_{f}\right)$ for material GH4133 at different temperatures $T$ and stresses $R$ are obtained and the equivalent local deformation $\varepsilon_{e q}$ is calculated by equation (7). Together with the values of $\varepsilon_{e q}$ and $N_{f}$, an exponential curve is obtained [27].

$$
\varepsilon_{e q}=0.004212 e^{\left(-0.0002079 N_{f}\right)}+0.005178 e^{\left(-0.000007551 N_{f}\right)},
$$

Based on the results of stress analysis (Table 3) of the segment of 1/49 part of the turbine disk and a modified model of Walker lifetime prediction (Eqs. (7) and (8)), the lifetime parameter $N_{f}$ was determined [28]. This, together with the known number of cycles for different operation modes (Table 2) makes it possible to estimate the turbine disk lifetime according to the Miner's formula [28]:

$$
D=\sum_{i=1}^{n} \frac{n_{i}}{N_{i}}=\frac{n_{1}}{N_{f 1}}+\frac{n_{2}}{N_{f 2}}+\frac{n_{3}}{N_{f 3}}=\frac{1220}{8885}+\frac{1850}{23701}+\frac{17320}{1001189}=0.3883 .
$$

As can be seen from Table 2, the measured rotational speed range is valid for $800 \mathrm{~h}$ of operation, so the turbine disk lifetime is:

$$
T=800 \cdot \frac{1}{D}=800 \cdot \frac{1}{0.3883}=2060 \text { годин. }
$$


It should be noted that it is difficult to find an ideal method for predicting the lifetime of GTE components, which could be applied to a wide range of materials and different load conditions. There is also no model that takes into account the effects of various kings of fatigue loads. Thus, under the simultaneous action of low-cycle fatigue and creep (taking into account the shape of the loading cycle, the effect of the ratchet mechanism and medium stresses), Zhu et al. [29] proposed a model for predicting the LCF-C lifetime.

$$
N_{f}=k\left(E_{p}-T_{0} \cdot \Delta W_{F L}\right)^{p}\left(\Delta \varepsilon_{i n} \sigma_{\max }\right)^{q},
$$

where $\Delta W_{F L}$ is the deformation energy density at the fatigue limit of the material, $E_{p}$ is a viscosity-based parameter used to describe fatigue and creep damage, $\Delta \varepsilon_{i n}$ is the range of inelastic deformations.

To confirm the feasibility and effectiveness of the viscosity-based LCF-C prediction model for high-temperature components, the predicted LCF-C lifetime is estimated for GH4133 using test data from [29] with different strain coefficients and temperature $\left(400{ }^{\circ} \mathrm{C}\right.$ and $\left.500{ }^{\circ} \mathrm{C}\right)$. Using equation (11), the general model for predicting the LCF-C lifetime is derived as [29]:

$$
N_{f}=4.99462 \cdot 10^{31}\left(E_{p}-1.7138 \cdot \Delta W_{F L}\right)^{-3.0382}\left(\Delta \varepsilon_{i n} \sigma_{\max }\right)^{-0.370252},
$$

where $\Delta W_{F L}=0.44248 \mathrm{MJ} \cdot \mathrm{m}^{-3}, \sigma_{\lim }=420.7 \mathrm{MPa}, E=1.992 \cdot 10^{5} \mathrm{MPa}$.

It was shown that different models can be used to predict the lifetime of GTE components, which are based on different operating parameters.

\subsection{Determination of the Stress-Strain State of the Compressor Blades}

The compressor is one of the main parts of the turbine. Its main functions are to supply air for combustion and to maintain the turbine under pressure [30]. High rotational speed (up to $11000 \mathrm{rpm}$ ), air pressure, and high temperatures in the compressor cause a lot of damage. If a foreign object enters the engine rotating at this speed, it penetrates the housing, passes through the impeller and deforms the turbine blades [31]. Such damage causes imbalance of the rotating unit, which leads to a shift of the shaft and loss of efficiency of the engine as a whole [32]. In addition to foreign objects damage (FOD), the causes of failure can be the development of creep, fatigue failure, intensification of vibration, corrosion damage. Failure of one blade can cause the gas turbine to stop [31]. In this direction, the problems of high-quality locking of threaded joints of thin-walled parts of aero-hydraulic channels of the GTE [33, 34] and the problem of vibration protection of power machines [35] remain relevant.

The failure of compressor blades is analysed in various works. In particular, Leong [36] analysed the effect of vibration on the compressor blades. Kermanpur et al. [37] found that the causes of failure of the 

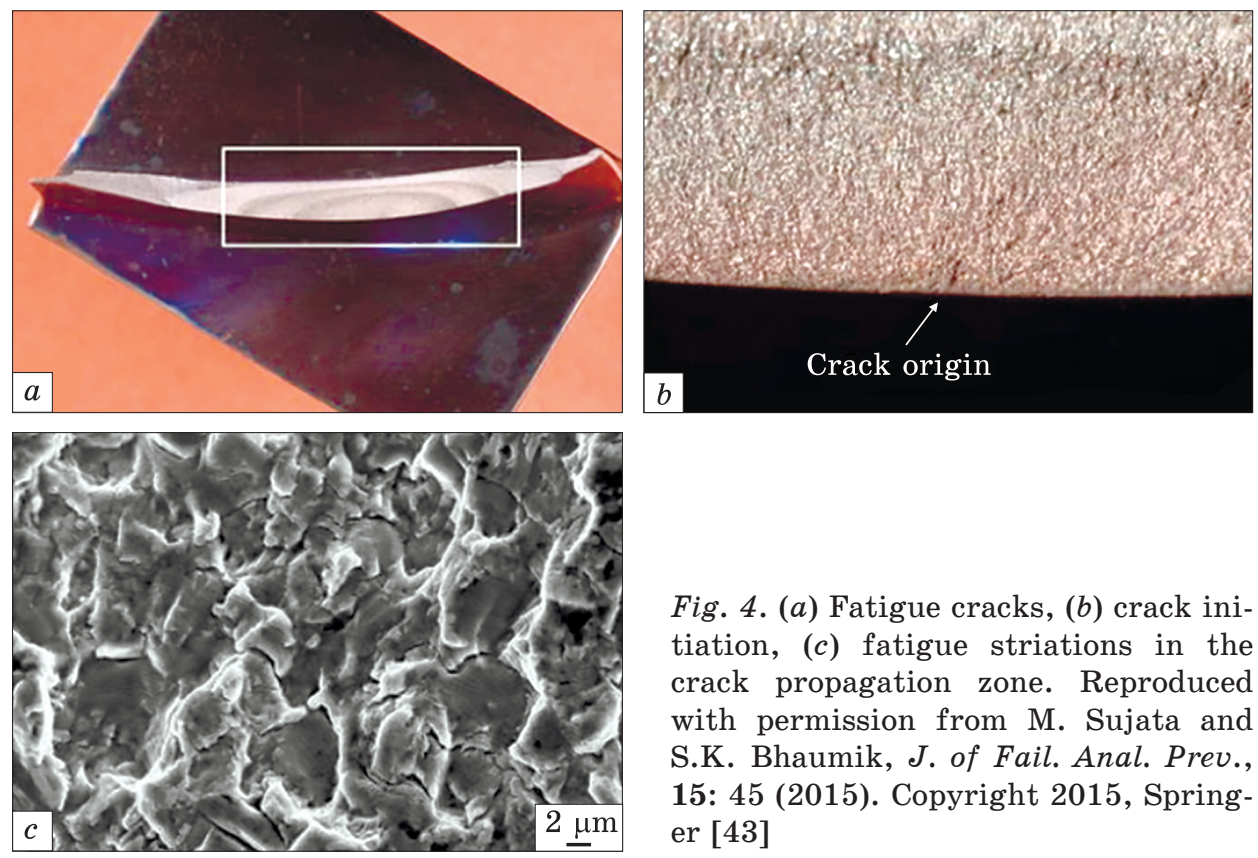

Fig. 4. (a) Fatigue cracks, (b) crack initiation, (c) fatigue striations in the crack propagation zone. Reproduced with permission from M. Sujata and S.K. Bhaumik, J. of Fail. Anal. Prev., 15: 45 (2015). Copyright 2015, Springer [43]

compressor blade made of Ti6Al4V titanium alloy [38] are poor connection of the blade base with the rotor and low wear resistance of the blade. Witek [39] calculated the stress state of the blade under operating conditions by the finite element method (FEM). Matheron et al. [40] using a cyclic tensile and torsion test created a database under conditions of biaxial fatigue. Tahmasbi et al. [41] simulated the effect of centrifugal and aerodynamic forces on the compressor blades made of composite materials using the finite element method (FEM). Hyeok-Jun Kwon et al. [42] analysed an accident with an engine fire due to compressor failure during take-off. The analysis showed that the microstructure of the fractured blades had larger grains compared to nonfractured blades. This indicates the development of creep in the material and premature fatigue cracking [42].

M. Sujata et al. [43] analysed the failure of the HPCR blade made of VT-6 titanium alloy in the aircraft engine during tests on the stand. Fractographic studies confirmed that the fracture occurred by a fatigue mechanism. At the time of the accident, the engine was running only $12.2 \mathrm{~h}$ out of the stated 1,500 h. Examination of the GTE showed that one of the blades of the first stage had a crack in the profile near the root (Fig. 4, a), which led to engine damage. Analysis of the fracture surface showed that the semi-elliptical crack with clearly defined edges, typical of fatigue failure, is formed in this area. Due to this, the location of the crack nucleation was identified (Fig. 4, b). 
Fractographic analysis confirmed the fatigue nature of crack propagation with typical fatigue striations, tears and dimples (Fig. 4, c). Analysis of data from the test stand showed the serviceability of the engine at a vibration level much lower than the maximum allowable for HPCR blades. Therefore, the failure occurred due to degradation of the blade material, and not due to deviations in the engine mode.

P. Rygiel et al. [31] investigated the negative impact of foreign objects (FOD) on the compressor blade using a comprehensive modal and harmonic analysis to simulate vibrations for blades with two types of damage, namely, of shapes "V" and "I" and for the blade without damage. Damage was simulated at five different depths $(0.1 ; 0.499 ; 0.999$; $1.999 ; 3.2 \mathrm{~mm})$ to obtain stress and vibration values $[31,42]$. The discrete model of the blade consists of a grid of tetrahedral elements, each of which contains 10 nodes. To increase the accuracy of the results around the damage, the grid was applied with smaller elements. The values of the frequency regime and the distribution of stresses in the blades were determined [31].

P. Rygiel et al. [31] found that the oscillation frequency decreases with increasing depth of damage, and the location of damage at the top and at the base of the blade does not affect the natural frequencies of the blade. These parameters can be traced on the contour maps of stress distribution according to von Mises [44].

Therefore, for the blade without damage, the area with the maximum stress is in the lower part of the output edge near the tail, and the stress in it is $398.69 \mathrm{MPa}$, and the stress in the blade body is $338.85 \mathrm{MPa}$. For a blade with shape "I" damage, the maximum stress at the notch tip is 1519.5 MPa, and the stress in the blade body is $354.78 \mathrm{MPa}$. For a blade with shape "V" damage, the maximum stress at the base of the damage is $1170.2 \mathrm{MPa}$, while the stress in the blade body is $347.8 \mathrm{MPa}$. From this, we can conclude that even small damage to the blades can increase the stresses in these areas several times, and, respectively, the lifetime of such blades is also significantly reduced. Shape "I" damage has a much worse effect on the lifetime and integrity of the blade than shape "V" damage, and the stresses in this case are much higher. Vibration stresses are distributed differently depending on the damage shape. Thus, dynamic calculations using the finite element method make it possible to correctly plan the following theoretical and experimental studies.

When considering shape "I" damage in thin-walled parts, it is also important to take into account the crack closure effect caused by bending loads [45-47]. 


\subsection{Monitoring Deformations by the Method of Correlation of Digital Images}

For the purpose of laboratory research of structural materials and practical control of elastic-plastic deformations of structural components the method of correlation of digital images (CDI) is widely used [48]. This method consists in software processing of a number of digital images of a surface of a body received in the course of its loading for the purpose of tracking of movements of a set of dots on this surface and the subsequent calculation of deformations. To implement the method, a natural or artificially created (for example, using elastic aerosol paint) stochastic dot pattern is performed on the surface [49-52]. The test surface is illuminated by an incoherent radiation source and the image of this surface is recorded using a matrix detector in the form of a CCD (charge-coupled device) matrix or a CMOS (complementary metal oxide semiconductor) matrix included in a video or digital camera. To implement the CDI, it is necessary to register the images of the original, i.e., non-deformed surface (image $a$ ) and the deformed surface (image $b$ ) (Fig. 5).

Images $a$ and $b$ recorded with a digital camera are stored as uncompressed digital images. A typical scheme of illumination of the optically rough surface of the sample of structural material and registration of images $a$ and $b$ is shown in Fig. 6.

Software algorithms for image processing by the CDI method are quite complex and are constantly being improved by software developers. The following describes only the principle of their work on a simple example.

Suppose it is necessary to measure the vertical $v$ and horizontal $u$ displacements of two arbitrary points $\boldsymbol{A}$ and $\boldsymbol{B}$ (see Fig. 5) located on the surface of the sample near the stress concentrator, caused by an external load, and to determine the deformation $\varepsilon$ on the base $b$ between these two points. The base, hereinafter, is the initial distance between points [53], the displacement of which is measured in order to determine the deformation. Each of these points is related to a pixel of the digital image. Therefore, it is necessary to find points $\boldsymbol{A}^{\prime}$ and $\boldsymbol{B}^{\prime}$ (pixels) in the image of the deformed surface corresponding to points $\boldsymbol{A}$ and $\boldsymbol{B}$. Since information about the shade of each of the pixels is not enough to unambiguously identify them in the image of the deformed surface (the image may have a significant number of pixels of this shade), then an area of rectangular or other shape is selected around each pixel, within which the distribution of shades of pixels is likely to be unique. This area serves as a marker to track the movement of a dot that is in its centre. Next, according to the appropriate algorithm embedded in the software, for the CDI in the image of the deformed surface, an area with 

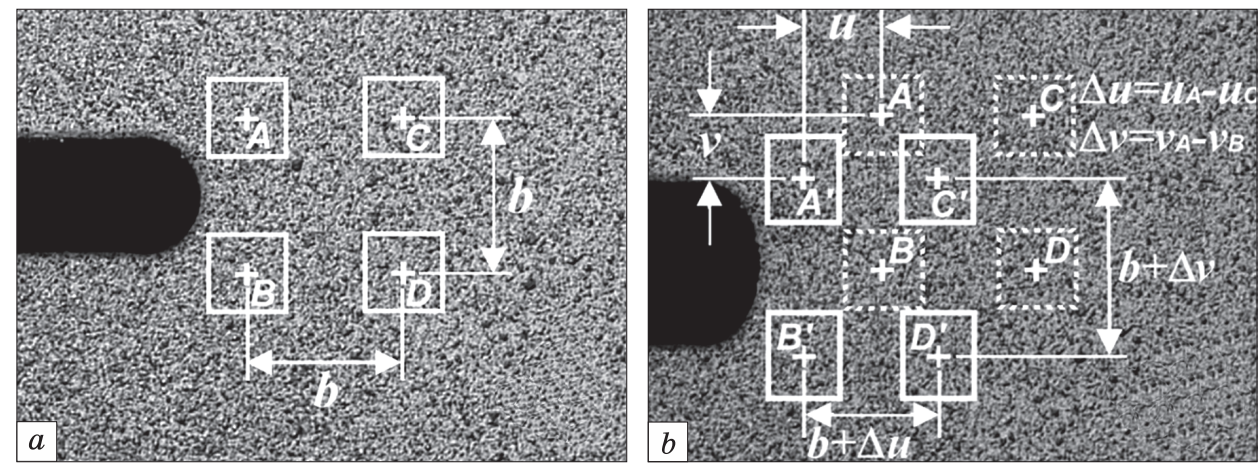

Fig. 5. The scheme for determining the displacements and deformations by the method of CDI: $a$ - non-deformed surface, $b-$ deformed surface. Reprinted with permission from Yu. V. Mol'kov, Otsinyuvannya Opirnosti Ruynuvannyu Yemnostey Pid Tyskom Iz Vykorystannyam Ehnergetychnoho Pidkhodu [Evaluation of Pressure Vessels Fracture Resistance Using Energy Approach], Ph.D. dissertation, Karpenko Physico-mechanical institute of the NAS of Ukraine, Lviv, Ukraine, 2014 (in Ukrainian) [49]

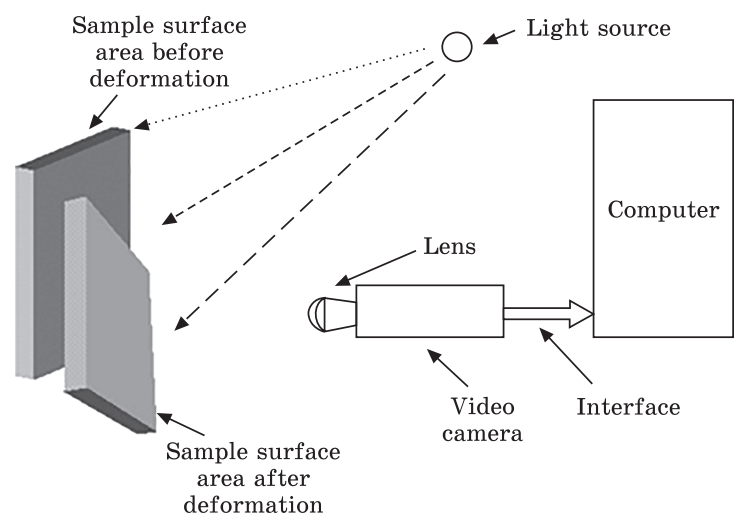

Fig. 6. The scheme of displacement measurements by the CDI method. Reproduced with permission from Yu.V. Mol'kov, Otsinyuvannya Opirnosti Ruynuvannyu Yemnostey Pid Tyskom Iz Vykorystannyam Ehnergetychnoho Pidkhodu [Evaluation of Pressure Vessels Fracture Resistance Using Energy Approach], Ph.D. dissertation, Karpenko Physicomechanical institute of the NAS of Ukraine, Lviv, Ukraine, 2014 (in Ukrainian) [49]

the same distribution of pixel shades is found. This determines the coordinates of the points $\boldsymbol{A}^{\prime}$ and $\boldsymbol{B}^{\prime}$ in the image of the deformed surface, and hence the components $u$ and $v$ of their displacement relative to the initial positions in the original image.

The deformation components are calculated according to the formulas embedded in the software algorithm:

$$
\varepsilon_{x x}=\frac{\partial u}{\partial x}+\frac{1}{2}\left[\left(\frac{\partial u}{\partial x}\right)^{2}+\left(\frac{\partial v}{\partial x}\right)^{2}\right] \quad \varepsilon_{y y}=\frac{\partial v}{\partial y}+\frac{1}{2}\left[\left(\frac{\partial u}{\partial y}\right)^{2}+\left(\frac{\partial v}{\partial y}\right)^{2}\right],
$$

The resolution (accuracy) of the measurements is determined by the resolution of the digital camera, the size of the measurement area (i.e., the scale of the images), and the software used. The software available today allows getting a resolution of 0.01 image pixel for a displacement 
and $0.01 \%$ for a relative deformation. For example, for an 8MP camera $(3264 \times 2448$ pixels $)$ on a surface area $326.4 \times 244.8 \mathrm{~mm}$ in size, the displacement resolution will be $1 \mu \mathrm{m}$. Accordingly, if we use the same camera to take picture of a smaller area, we will get a higher resolution and vice versa.

Thus, at a micron ( 1 pixel $\leq 1 \mu \mathrm{m})$ image scale, the accuracy of the CDI method significantly exceeds the accuracy of measuring displacements by mechanical means. When solving the problems of fracture mechanics, the CDI can successfully compete with such precision methods as phase-shift interferometry, however, in contrast to this method, the CDI is much simpler to use.

\section{Material Selection for Blades and Discs of the Gas Turbine Engine}

\section{1. Structure and Phase Composition of Functional Materials}

As a rule, modern design solutions compete with the ideology of the choice of materials. For example, the use of expensive heat-resistant alloys increases the total cost of the GTE, but reduces the need for constant cooling during operation. On the other hand, the use of a more complex and highly efficient cooling system of turbine blades also increases their cost, but allows the use of less expensive and well-studied materials [54].

Heat-resistant materials (high-alloyed materials based on $\mathrm{Ni}, \mathrm{Co}$, and $\mathrm{Fe}$ ) are used in the constructions of aircraft, space, marine, and groundbased gas turbine engines and in nuclear power plants. Among them, the main place is occupied by nickel-, iron, and iron-nickel-based alloys [55-57]. Heat-resistant nickel alloys (HRNA) are used to manufacture the most responsible heavy-duty parts of the hot path of the GTE. Turbine and nozzle blades of civil and military aircraft are cast from them [58]. It should be noted that the chemical composition of these alloys implies the presence of a large number of alloying elements with high solubility in the crystal lattice of the base. Thus, the microstructure of the alloy consists of a high-alloyed $\gamma$ solid solution, prone to thermal or deformation aging with the formation of a mechanical mixture of $(\gamma+$ $+\gamma^{\prime}$ ) phases [59]. The $\gamma^{\prime}$ phase is usually intermetallics of the $\mathrm{Ni}_{3} \mathrm{Al}$ type with f.c.c. lattice or other dispersed secondary phases (oxides, carbides, oxycarbides, oxynitrides, carbonitrides, borides, etc.) [60]. They reinforce the main matrix $\gamma$ phase and counteract the increase in the size of its grains. It is this microstructure of the alloy that resists the development of creep, provides long-term strength and crack growth resistance under the influence of high temperatures [61]. For a long time, the development of such alloys was carried out empirically. Currently, computer-modelling methods are widely used, which allow to find quickly and reliably the optimal composition of alloys with a predetermined structure and level of performance [62-64]. 
According to the international classification, there are five generations of HRNA type JS for casting single-crystal blades of aircraft engines. First-generation alloys contain traditional alloying elements, such as $\mathrm{Al}, \mathrm{Ti}, \mathrm{Cr}, \mathrm{Mo}, \mathrm{W}, \mathrm{Ta}, \mathrm{Nb}$, and Hf. Alloys of the second and third generations are additionally alloyed with $\mathrm{Re}$ in an amount of from $2-4 \%$ to $5-6 \%$, respectively. The fourth and fifth generations include alloys alloyed with $\mathrm{Ru}$. Each subsequent generation of HRNA allowed increasing the operating temperature of the turbine blades by $20-25{ }^{\circ} \mathrm{C}[54$, 65]. Cast HRNA belong to the class of dispersion-hardening high-temperature materials. The main hardening in them is achieved by coherent cube-shaped particles $(\leq 0.5 \mu \mathrm{m})$ of $\gamma^{\prime}$ phase based on $\mathrm{Ni}_{3} \mathrm{Al}$ type intermetallic, which are formed by the decomposition of supersaturated $\gamma$ solid solution during cooling to a temperature below $\gamma^{\prime}$ solvus or during isothermal exposure [66]. Both phase components have isomorphic f.c.c. lattices, with the only difference that the $\gamma$ phase is a nickel-based disordered substitutional solid solution with a crystal lattice period that differs slightly $(\leq 0.3 \%)$ from such a solution of an ordered $\gamma^{\prime}$ phase. Along with the hardening of the $\gamma^{\prime}$ phase, dispersion hardening by particles of carbides and borides of various types is realized in HRNA. The total volume content of the particles reaches 1.5-2\%. Thus, HRNA consists of a complex-alloyed nickel-based $\gamma$ solid solution, intermetallic $\gamma^{\prime}$ phase, and monocarbides of the $M \mathrm{C}$ type (where $M=\mathrm{Ti}, \mathrm{Ta}, \mathrm{Nb}$, and $\mathrm{C}$ is carbon) or borides of various types. The volume fraction of dispersed particles of the $\gamma^{\prime}$ phase in the microstructure of such alloys can reach 60-70\% . In HRNA of eutectic type with microstructure of the composite $\gamma / \gamma^{\prime}$ type, MC carbide hardening is decisive. The carbide phase formed by controlled crystallization from the melt is characterized by a flat growth front of monocarbides, which in the form of continuous chains of fibrous type are precipitated at high temperatures and provide a composite mechanism for strengthening the alloys [65]. The operating temperatures of modern heat-resistant alloys approach the temperature intervals of dissolution of the hardening phases: $\gamma^{\prime}$ phase, carbides, etc. Therefore, to increase the creep resistance at temperatures above $950{ }^{\circ} \mathrm{C}$, it is necessary not only to optimize the proportion of strengthening phases, but also to maximize the temperature range of its dissolution $[65,67]$.

In addition to the volume fraction of dispersed particles of the $\gamma^{\prime}$ phase, the heat resistance of nickel alloys increases due to the hightemperature stability of the phases of which they consist. This is determined by the thermodynamic and kinetic parameters of the system. The thermodynamic parameters include the isotherms of the lines of phase transformations, in particular, the temperature of complete dissolution of the dispersed $\gamma^{\prime}$ phase in $\gamma$ solid solution, called the nonequilibrium solidus, known in the literature as the local melting point. These tem- 
peratures not only characterize the thermal stability of the phases, but also determine the heat resistance [68]. Kinetic parameters are the diffusion coefficients of alloying elements in $\gamma$ solid solution, which indirectly determine the rate of their dissolution and the degree of coagulation of the $\gamma^{\prime}$ phase particles and, as a consequence, the gradual decrease in the material creep resistance. There is a correlation between the diffusion coefficient $D$ and the entropy product $T S$. In particular, if alloying increases $T S$, other things being equal, the diffusion mobility of atoms in such an alloy will be lower [69]. The parameters of the microstructure that determine the stability of alloys at high temperatures include the periods of crystal lattices of both the $\gamma$ solid solution and the $\gamma^{\prime}$ phase and their dimensional mismatch $\Delta=\left(a \gamma-a \gamma^{\prime}\right) / a \gamma^{\prime}$, which characterize the level of solid solution strengthening of the phases. The sign of the parameter $\Delta$ determines the shape of dispersed particles of the $\gamma^{\prime}$ phase. When $\Delta<0$, the $\gamma^{\prime}$ phase particles have morphology similar to the morphology of dendritic crystallites. When $\Delta=0$, the particles are characterized by a spherical shape, and at positive values of $\Delta=0.2-0.3 \%$, which are most common, such particles have a shape close to the cubic [68]. The long-term strength tests of the studied alloys showed [70] that their durability increases with decreasing absolute values of the mismatch parameter of crystal lattices of the $\gamma$ and $\gamma^{\prime}$ phases mainly in the negative region of its values. At the same time, alloys with a small positive value of dimensional mismatch $(\Delta \cong 0.3 \%)$ of lattice periods of the $\gamma$ and $\gamma^{\prime}$ phases have the greatest heat resistance [68]. Thus, during the alloying of heat-resistant alloys, in addition to the total strengthening provided by a certain $\gamma$ to $\gamma^{\prime}$ quantitative ratio in their microstructure and by the particle sizes of these phases, it is necessary to provide a certain positive value of dimensional mismatch of lattice periods of the $\gamma$ and $\gamma^{\prime}$ phases and a slight dependence of this parameter on temperature [68].

The temperature level of phase transformations determines some technological properties of alloys. In particular, the supercooling degree $\Delta T c r=(T L S-T)$ in the process of directed crystallization characterizes the tendency of alloys to form a columnar or single-crystal structure of castings and the volume fraction of microporosity [71]. This provides the possibility of high-temperature homogenization without the risk of melting of the interdendritic regions and reduces the sensitivity of the alloy to overheating [54].

\subsection{The Concept of Alloying Heat-Resistant Alloys}

The main principle of alloying heat-resistant alloys is to improve the heterophase structure, where in the fine-dispersed base of the solid solution should be evenly distributed fine-dispersed inclusions of the 
reinforcing phases. At the same time, the increased stability of intergranular surfaces and interface boundaries of other phases should be preserved [72].

The elements used for alloying such alloys can be divided into three groups [65, 73]:

- soluble elements involved in the formation of $\gamma$ solid solution;

- elements involved in the formation of $\gamma^{\prime}$ phase;

- carbide-forming or nitride-forming elements.

As already mentioned, the probability coefficients of the distribution of alloying elements between the $\gamma^{\prime}$ and $\gamma$ phases are the microstructure parameters that most respond to the formation of the phase composition of HRNA [73]:

$$
K_{p}=C_{i \gamma}{ }^{\prime} / C_{i \gamma},
$$

where $C_{i \gamma}{ }^{\prime} / C_{i \gamma}$ are concentrations (\%) of the $i$-th element in the $\gamma^{\prime}$ and $\gamma$ phases, respectively.

The first group of alloying elements includes $\mathrm{Cr}, \mathrm{Mo}, \mathrm{Re}, \mathrm{Ru}, \mathrm{Co}$, $\mathrm{Ir}, \mathrm{V}$, and $\mathrm{W}$. The coefficients of their distribution between the $\gamma^{\prime}$ and $\gamma$ phases are less than one. The second group includes $\mathrm{Al}, \mathrm{Ti}, \mathrm{Nb}, \mathrm{Ta}, \mathrm{Hf}$, and $\mathrm{Pt}$, for which the distribution coefficients $K_{i}>0.1$. The following alloying elements are carbide-forming or nitride-forming: $\mathrm{Ti}, \mathrm{Ta}, \mathrm{Nb}$, Hf, V, W, Mo, and Co. It should be noted that Re is characterized by the highest solubility in the $\gamma$ phase and, accordingly, the lowest solubility in the $\gamma^{\prime}$ phase, and its distribution coefficient is $K_{i} \cong 0.1$ [73].

A special group includes elements that are used during microalloying and the main role of which is to stabilize the intergranular and interphase boundaries to prevent the tendency of the grain structure to grow or coagulate the reinforcing phases. These are $\mathrm{C}, \mathrm{B}, \mathrm{Zr}$, and some rare-earth elements (La, Ce, and Y). Their concentrations in heat-resistant alloys vary within thousandths or hundredths of a percent [74].

Since in the process of high-temperature creep the fracture of heatresistant alloys with equilibrium microstructure occurs along the transverse (relative to the effective stresses) grain boundaries, for a long time traditional alloying systems aimed at stabilizing alloy microstructure were used to increase heat resistance. The performance properties of such alloys increased with increasing $\mathrm{Al}$ concentration, additional alloying with refractory metals (Mo, W, Ta, and Hf) and microadditives ( $\mathrm{Zr}, \mathrm{Y}, \mathrm{La}$, and Ce). Besides, the plasticity of alloys and their thermal stability decreased, which led to a significant scatter in the values of mechanical properties [75].

Therefore, the optimization of the chemical composition of such alloys involves the selection of such a combination of alloying elements, which would provide the maximum volume fraction of the reinforcing $\gamma^{\prime}$ phase. The microstructure of the alloys for a long time in a wide range 
of operating temperatures must maintain a stable mechanical mixture of the $\left(\gamma+\gamma^{\prime}\right)$ phases. Otherwise, the transformation of the structure of alloys by phase composition or dimensional parameters of the phases leads to premature nucleation of defects and propagation of microcracks. Another indirect reason for the gradual degradation of alloys is due to the fact that the grains of the basic $\gamma$ solid solution are depleted of alloying elements, and the particles of the reinforcing $\gamma^{\prime}$ phase are first coagulated and then completely dissolved in the solid solution. This first reduces and then eliminates the efficiency of concentrated solid-solution and dispersion strengthening. In this case, the parameters of the stability of the microstructure and, accordingly, the functional properties change unfavourably [54].

Of particular note is such an alloying element of HRNA as Re. It was found that of all the elements Re most effectively increases the heat resistance of nickel alloys due to the fact that it has a low diffusion coefficient and inhibits the diffusion mobility of atoms in the $\gamma$ phase, and thus reduces the rate of coagulation of the reinforcing $\gamma^{\prime}$ phase particles. It should be noted that in heat-resistant alloys of the second generation, the concentration of Re was about 2 wt.\%, while in the third generation alloys, it is increased to $6 \mathrm{wt} . \%$. The positive effect of rhenium on the heat resistance of nickel alloys is also due to the increase in both solidus temperature and the solubility of rhenium in $\gamma$ solid solution, which accordingly causes an increase in the period of its crystal lattice [76]. At temperatures above $1100{ }^{\circ} \mathrm{C}$, the positive effect of Re on heat resistance is reduced due to phase instability of $\gamma$ solid solution. During its decomposition, lamellar particles of rhenium-enriched phases are precipitated. As a result, the resistance to dislocations slip decreases and structural inhomogeneity occurs, which reduces the thermal stability and heat resistance characteristics. Fourth and fifth generation alloys are additionally alloyed with ruthenium, which has advantages over rhenium. It has a lower density than rhenium, is not prone to the formation of embrittlement phases, practically does not cause liquation in the process of directed crystallization. Due to the high cost of rhenium and ruthenium, heat-resistant alloys based on the $\mathrm{Ni}_{3} \mathrm{Al}$ intermetallic are being developed [54, 76].

Another important alloying element, which significantly increases the thermal stability due to the precipitations of the reinforcing $\gamma^{\prime}$ phase and changes the lattice period of $\gamma$ solid solution is tantalum. An additional increase in the heat resistance of dispersion-hardened alloys can be achieved by alloying with carbide-forming elements, which in addition to tantalum include $\mathrm{Cr}, \mathrm{V}, \mathrm{W}$, and $\mathrm{Nb}$. Chromium carbide has a strong tendency to coagulation and does not allow obtaining a large strengthening effect at high temperatures [77]. In addition, the reduction of the chromium content in the $\gamma$ solid solution due to the forma- 
tion of carbides leads to the decomposition of the $\gamma$ phase. Tantalum increases the level of the mechanical properties of nickel alloys not only due to the strengthening of $\gamma$ solid solution and the $\gamma^{\prime}$ phase, but also due to the formation of tantalum monocarbide, which is more strongly bound to the matrix compared to other types of carbides. However, this carbide does not participate in the dispersion hardening [78].

\subsection{Surface Protection Methods for the Main Elements of the Gas Turbine Engine}

Because gas turbine engines operate in aggressive environments at elevated temperatures, their surface is damaged as a result of stress and high-temperature corrosion [79]. Therefore, to create a protective layer that will combine corrosion resistance and resistance to cracking, increase the lifetime and improve the performance of the GTE components, protective coatings are applied to some structural components [80].

There are established approaches to the application of protective coatings on the GTE parts, depending on operational factors. In particular, parts of the cold section of the engine, which includes the fan and compressor, are damaged mainly by erosion and corrosion. The parts of the hot section, which includes the combustion chamber and the turbine, are usually damaged by hot gases, which are formed due to fuel combustion and cause oxidation and corrosion of parts [54, 81]. Therefore, it is important to conduct corrosion studies of metals and coatings in the stressed state [82, 83].

Erosion-resistant coatings are applied to the compressor blades. The bases of the compressor blades, which have the shape of a dovetail, are coated with anti-fretting coatings that protect against fretting corrosion. Wear-resistant coatings are used for housings, tips and seals. Anti- corrosion coatings protect the gas turbine blades. Thermal barrier coatings protect the blades of the flowing part, the jet pipe and the nozzle of the gas turbine.

Various technologies are used for coating, including chemical vapour deposition (CVD) [84], physical vapour deposition (PVD) [84, 85], air-plasma spraying (APS) [86, 87], laser surface alloying [88-91], ion implantation, etc. This allows the formation of coatings for different functional purposes: adhesive, diffusion, adhesive-diffusion coatings [92-97], and layered coatings [98]. Weld repairing is used to restore parts with crack-like defects $[99,100]$.

To create a CVD coating, it is necessary to create specific technological and thermodynamic conditions. The use of appropriate pressure, temperature, quantity and flow of reagents (usually $\mathrm{AlCl}_{3}+\mathrm{H}_{2}$ ) allows forming heat-resistant diffusion coatings based on NiAl intermetallic. For example, the formation of heat-resistant aluminide coatings in- 
Fig. 7. The microstructure of aluminide coating [101]. Reproduced with permission from M. Hetmanczyk et al., , J. of Ach. Mater. Manuf. Engin., 24, No.1: 372 (2007); https://www.researchgate. net/publication/40804836_Advanced_materials_and_protective_coatings_in_aero-engines_ application. Copyright 2007, International OCSCO World Press [101]

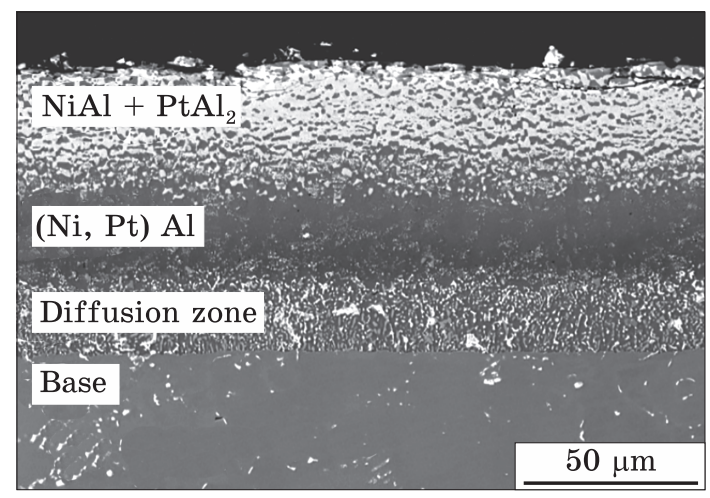

creases the resistance of the blades to oxidation, which is desirable at elevated temperatures [84]. To increase the oxidation resistance of heatresistant steels and alloys, coatings should be multilayer to ensure good adhesion, resistance to elevated temperatures and aggressive environments [54]. This is confirmed in the works of many authors, in particular in [101], which deals with the technology of applying multilayer diffusion coatings modified with platinum, obtained by the processes of platinumization and aluminization (Fig. 7).

In turn, PVD coatings are applied in vacuum chambers and usually use high-energy sources, such as an electron beam in the EV-PVD method or arcing in the Arc-PVD method. The coating is formed due to the deposition of ionized atoms at a certain temperature, which is measured on the surface of the coated parts. PVD methods allow applying coatings uniformly on thickness and with ideally smooth surface that improves wear resistance of the coated parts. These coatings do not even require additional processing. Electron beam physical vapour deposition (EBPVD) is the most technologically advanced PVD method, which is currently the best for applying thermal barrier coatings (TBC) [81]. These coatings are two-layer coating systems consisting of corrosion and oxidation resistant inner layer $\mathrm{MeCrAlY}(\mathrm{Me}=\mathrm{Ni}, \mathrm{Co}, \mathrm{Fe})$, which is called a bonding coating, and insulating outer ceramic layer $\mathrm{ZrO}_{2} \times \mathrm{Y}_{2} \mathrm{O}_{3}$, or "top layer" [102-104]. Low thermal conductivity, which is characteristic of ceramic materials, causes a decrease in temperature, which increases the resistance of the material surface to oxidation. The most common methods of obtaining thermal barrier coatings, in addition to EB-PVD method, are APS (air-plasma spraying) and LPPS (low-pressure plasma spraying) methods [105, 106].

Coatings based on yttria-stabilized zirconia ceramics $\left(\mathrm{ZrO}_{2} \cdot 8 \mathrm{Y}_{2} \mathrm{O}_{3}\right)$, which are applied by air-plasma spraying, have proved to be very good as thermal barrier coatings (Fig. 8). The thickness of the ceramic zone is $300 \mu \mathrm{m}$, and the thickness of the intermediate coating $\mathrm{MeCrAlY}$ is about $100 \mu \mathrm{m}$ [101]. 


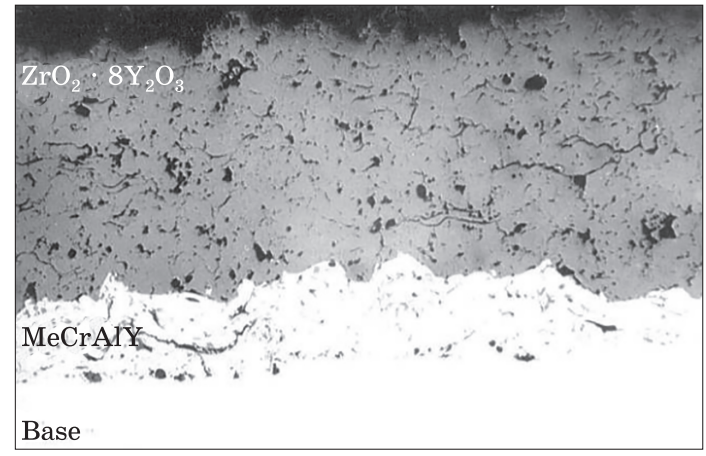

Fig. 8. The microstructure of barrier coating. Reproduced with permission from M. Hetmanczyk et al., J. of Ach. Mater. Manuf. Engin., 24, No.1: 372 (2007); https://www.researchgate.net/ publication/40804836_Advanced_ materials_and_protective_coatings_in_aero-engines_application. Copyright 2007, International OCSCO World Press [101]

TBC, which are applied by air-plasma spraying and EB-PVD technology, differ in their microstructure and properties. Plasma spraying coatings have a tape microstructure, while EB-PVD coatings have a columnar microstructure. Thermal barrier plasma coatings are more vulnerable to thermal stresses, which can cause initiation and propagation of microcracks, and this can lead to the coatings cracking [107-112].

Damage to the material in a corrosive environment often leads to premature fatigue failure $[113,114]$. In addition, the GTE components are also prone to erosion due to the continuous action of powerful airflow. Such damage most often appears in the working areas of the compressor blades [111-114]. Therefore, erosion-resistant coatings are also used, which prevent premature loss of blade material due to mechanical interaction between blade surfaces and solid particles or a liquid. The Arc-PVD method is used to apply erosion-resistant coatings. This method allows the application of multilayer coatings of chromium nitride and is characterized by a high degree of ionization [115, 116]. This coating is perfectly adapted to the operating conditions, as it is characterized by alternating soft and hard layers [117]. When solid particles hit the surface of the blades, cracking of the hard and brittle top nitride layer of such a coating may occur, but further spread of the particles to the depth of the blade is blocked by a soft chrome layer of the coating that traps the particles. The hardness of the top coating layer is 2800 $3200 \mathrm{HV}$, and the operating temperature is in a range of $60{ }^{\circ} \mathrm{C}$ to $600{ }^{\circ} \mathrm{C}$ [80]. The tests of engines shown in [118] confirmed the advantage of multilayer erosion-resistant $\mathrm{Cr} / \mathrm{CrN}$ coatings compared to $\mathrm{Ti} / \mathrm{TiN}$ coatings in many parameters. Niobium carbide-based coatings can also be promising [119].

\subsection{Ranking of Alloys by Shear Crack Resistance}

Studies [120] of multi-support locking joints of GTE blades have shown that fatigue cracks occur in the upper teeth of discs due to long-term operation. Their growth occurs under a complex stress state. Therefore, 
in determining their lifetime, the stress intensity factors $K_{\mathrm{I}}$ (normal tension) and $K_{\text {II }}$ (transverse shear) are decisive (Table 4). In contrast to the method of determining the crack growth resistance characteristics at transverse shear $\left(K_{\mathrm{II}}\right)$, the method of determining the crack growth resistance characteristics at normal tension $\left(K_{\mathrm{I}}\right)$ is studied in detail. Therefore, in this case, more attention is paid to the study of the crack growth process at transverse shear. In view of this, the fatigue threshold $\Delta K_{\text {II } t h}$, which indicates the beginning of the growth of fatigue shear macrocracks, is an important structurally sensitive characteristic for the ranking of metallic materials of GTE components. To date, there is little information in the literature about this characteristic of crack growth resistance in general (Fig. 9) [121-125].

$K_{e}$ is the equivalent stress intensity factor that takes into account the two fracture macromechanisms.

$K_{e}^{s y m}$ is the equivalent stress intensity factor calculated for the case of a symmetrical crack, i.e., a crack with two opposite tips.

According to known methods [126, 127], to study the crack propagation under conditions of transverse shear, samples that require alternative solutions are used. Based on the analysis of theoretical and experimental studies [120,126-129], it is proposed to use a square-shaped sample with an edge notch $h$ (Fig. 10).

According to the loading scheme of the sample, the force $P$ is cyclically applied along the notch plane, until the fatigue shear crack of total length $l$ is formed in this plane.) It was important to build $K$ calibration dependences to determine the stress intensity factor (SIF) $K_{\text {II }}$ in the vicinity of the edge crack tip. For this purpose, within the framework of linear fracture mechanics, a mathematical model [130] of a square plate with an edge crack was formulated, which is a prototype of the proposed sample. To determine SIF $K_{\text {II }}$, the finite element method (FEM) and, as an alternative, the method of singular integral equations (SIE) were used.

Table 4. Stress intensity coefficients for the lock joints of the gas turbine blade in stationary mode. Adapted from N.G. Shul'zhenko, P.P. Gontarovskii, and I.I. Melezhik, Str. Mater., 40, No. 5: 566 (2008). Copyright 2008, Springer [120]

\begin{tabular}{|c|c|c|c|c|}
\hline Crack depth, mm & $K_{I}, \mathrm{MPa} \sqrt{m}$ & $K_{I I}, \mathrm{MPa} \sqrt{m}$ & $K_{e}, \mathrm{MPa} \sqrt{m}$ & $K_{e}^{\text {sym }}, \mathrm{MPa} \sqrt{m}$ \\
\hline 0.5 & 33.07 & 27.95 & 51.54 & 50.81 \\
1.0 & 27.34 & 39.49 & 53.46 & 51.48 \\
1.5 & 23.48 & 33.72 & 53.15 & 50.29 \\
2.0 & 20.77 & 33.73 & 52.02 & 48.41 \\
2.5 & 18.80 & 33.28 & 50.69 & 46.44 \\
3.0 & 17.50 & 32.74 & 49.50 & 44.67 \\
4.0 & 15.54 & 31.98 & 47.82 & 31.66 \\
5.0 & 14.58 & 31.39 & 47.39 & 30.42 \\
\hline
\end{tabular}



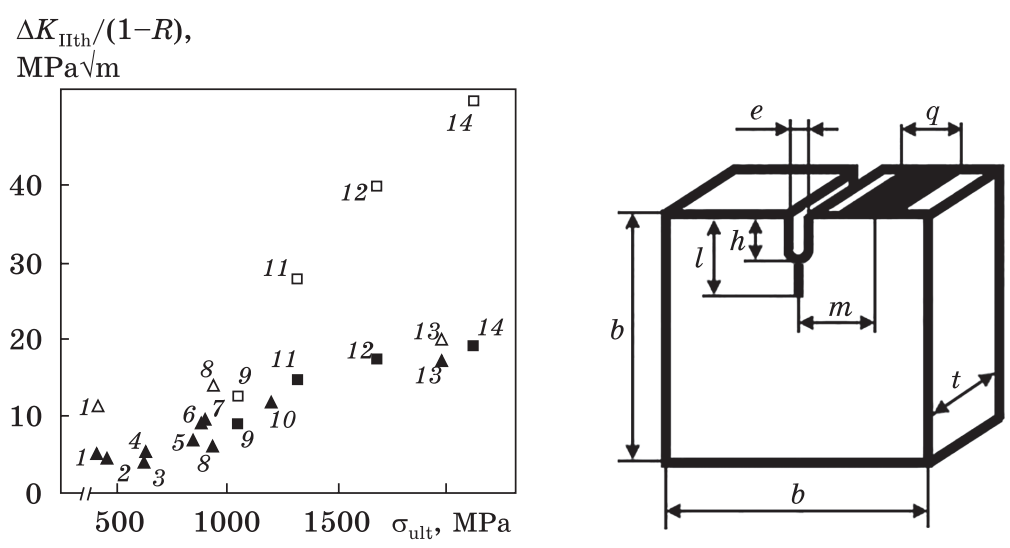

Loading scheme

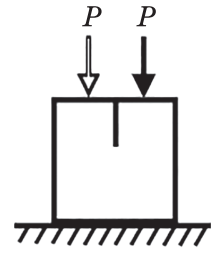

Fig. 9. Dependence of fatigue thresholds at transverse shear on the strength limit of steels [121] according to the results obtained from the standard [127] $(\square, \square)$ and according to the literature data ( $\boldsymbol{\Delta}, \Delta$ taking into account crack faces friction (CFF) $(\boldsymbol{\Delta}, \boldsymbol{\square})$ and without it $(\Delta, \square): 1-\operatorname{SS} 41(R=-1), 2-$ low carbon steel $(R=0.29)$, 3 - S45C $(R=-1), 4$ - steel with $0.47 \% \mathrm{C}(R=-1), 5$ - wheel steel $(R=0.33)$, $6-\mathrm{SKH}(R=-1), 7-\mathrm{GH}(R=-1), 8-$ rail steel $(R=-1), 9-65 \Gamma(R=-1)$, $10-\mathrm{SKH}(R=-1), 11-65 \Gamma(R=-1), 12-65 \Gamma(R=-1), 13-\mathrm{M} 250(R=0)$, $14-65 \Gamma(R=-1)$. Reproduced with permission from T.M. Lenkovs'kyi, Mater. Sci., 53, No. 2: 200 (2017). Copyright 2017, Springer [121]

Fig. 10. Square specimen with edge notch for cyclic shear test. Reprinted with permission from T.M. Lenkovs'kyi et al., Mater. Sci., 55, No. 4: 492 (2020). Copyright 2020, Springer [130]

During the creation of the calculated FEM model (Fig. 11, a), the usual three-dimensional 20-node prismatic isoparametric elements, special 15-node elements with shifted nodes, which reproduced the singularity of stress distribution in the crack tip vicinity, and 8-node elements for implementation of smooth contact of crack faces were used. The coefficient of crack faces friction (CFF) was taken $f_{c}=0$. Using the results of previous work [131], a cube-shaped submodel was built, which contained the crack tip. Next, the submodel was completed with conventional elements to a full-scale three-dimensional model (Fig. 11, b) of a square plate with a base size of $b=50 \mathrm{~mm}$ (see Fig. 9), thickness $t=1 \mathrm{~mm}$, contact spot length $q=10 \mathrm{~mm}$, distance from the notch plane to the centre of the contact spot $m=10 \mathrm{~mm}$ and the edge crack in the form of a mathematical section $(e=0)$ taking into account the smooth contact of its faces. The traditional characteristics were set for the material of the model: Young's modulus $E=210 \mathrm{GPa}$ and Poisson's ratio $\mu=0.3$. The plane strain conditions were imposed on the model. The model was clamped on the plate in the same way as the sample (see Fig. 10), limiting the displacement of the nodes of the face perpendicu- 
lar to the plane of the crack. The static load was implemented by the pressure $p_{0}$, evenly distributed over the contact $\operatorname{spot} q$, which is equivalent to the concentrated force $P=1 \mathrm{~N}$. The shear of the crack edges was determined in the plane in the middle of the crack front by the displacements of the nodes (Nos. 1-4) in special elements (Fig. 11, $b$ ) for which the parameter $c=12.5 \mu \mathrm{m}$. SIF $K_{\text {II }}$ was calculated by the formula valid for the plane strain conditions:

$$
K_{\mathrm{II}}=\frac{G}{2(1-\mu)} \sqrt{\frac{\pi}{2 c}}\left[\left(4 u_{2}-u_{4}\right)-\left(4 u_{1}-u_{3}\right)\right],
$$

where $G=E /(2(1+\mu)), E$ is Young's modulus, $\mu$ is Poisson's ratio; $u_{1} \ldots u_{4}$ are displacements of nodes with corresponding numbers.

Analysing the obtained results for SIF $K_{\mathrm{II}}$ calculated by two independent methods (Table 5), we note their good correlation. Calculating the relative deviation of $K_{\text {II }}$ values determined by the SIE method from the values obtained by the FEM method, we see that the largest discrepancy exists for the smallest and largest relative crack lengths $\varepsilon$ and does not exceed $3.5 \%$. For the range $\varepsilon=0.3 \ldots 0.7$, the maximum deviation is $1.7 \%$, which can be considered a good convergence of the calculation results.

By introducing the value of the normalized SIF $Y_{\mathrm{II}}=K_{\mathrm{II}} \cdot t \cdot b^{0.5} / P$, a $K$-calibration curve was constructed (Fig. 12), which takes into account contact without CFF. It was found that in the area of $\varepsilon=0.2 \ldots 0.5, Y_{\text {II }}$ values increase, and in the area of $\varepsilon=0.5 \ldots 0.8$, the curve bends downward, indicating a decrease in $Y_{\text {II }}$ values. It should be noted that the

Table 5. The value of a single SIF $K_{I I}$ for a square plate with an edge crack $\left(f_{\mathrm{c}}=\mathbf{0}\right)$

\begin{tabular}{|c|c|c|c|c|c|c|c|c|}
\hline \multicolumn{2}{|l|}{$\varepsilon$} & 0.2 & 0.3 & 0.4 & 0.5 & 0.6 & 0.7 & 0.8 \\
\hline$K_{I I}^{(F E M)}$ & \multirow{2}{*}{$\mathrm{Pa} \sqrt{m}$} & 1874 & 2312 & 2460 & 2492 & 2475 & 2420 & 2268 \\
\hline$K_{I I}^{(S I E)}$ & & 1811 & 2321 & 2501 & 2528 & 2485 & 2422 & 2348 \\
\hline$\delta$ & $\%$ & 3.362 & 0.389 & 1.667 & 1.445 & 0.404 & 0.083 & 3.527 \\
\hline
\end{tabular}

Table 6. Formulas for SIF $Y_{I I}$ calculation in a square plate with an edge crack

\begin{tabular}{|l|l|l|l|c|c|}
\hline $\begin{array}{c}\text { Normalized SIF } \\
Y_{I I}=K_{I I} \cdot t b \cdot 0.5 / P\end{array}$ & $\begin{array}{c}\text { Applicability } \\
\text { range }\end{array}$ & $\begin{array}{c}\text { CFF conside- } \\
\text { ration }\left(f_{c}>0\right)\end{array}$ & $\begin{array}{c}\text { Finite } \\
\text { plate }\end{array}$ & $\begin{array}{c}\text { Method of } \\
\text { obtaining }\end{array}$ & $\begin{array}{l}\text { Reference } \\
\text { source }\end{array}$ \\
\hline $\begin{array}{l}-0.2438+5.8482 \lambda- \\
-16.729 \lambda^{2}+23.175 \lambda^{3} \\
-15.015 \lambda^{4}+3.2917 \lambda^{5}\end{array}$ & $\varepsilon=0.2 \ldots 0.8$ & $\begin{array}{l}\text { Not taken } \\
\text { into account }\end{array}$ & $\begin{array}{l}\text { Taken into } \\
\text { account }\end{array}$ & FEM & {$[132]$} \\
\hline $\begin{array}{l}0.226+1.21 \varepsilon- \\
-1.068 \varepsilon^{2}-0.648 f_{c}+ \\
+0.115 f_{c}^{2}+0.25 \varepsilon f_{c}\end{array}$ & $\varepsilon=0.2 \ldots 0.8$ & $\begin{array}{l}\text { Taken into } \\
\text { account }\end{array}$ & $\begin{array}{l}\text { Not } \\
\text { taken into } \\
\text { account }\end{array}$ & SIE & {$[130]$} \\
\hline
\end{tabular}




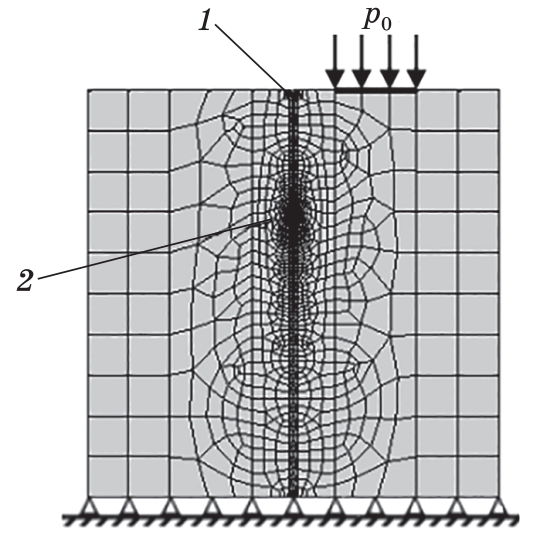

$a$

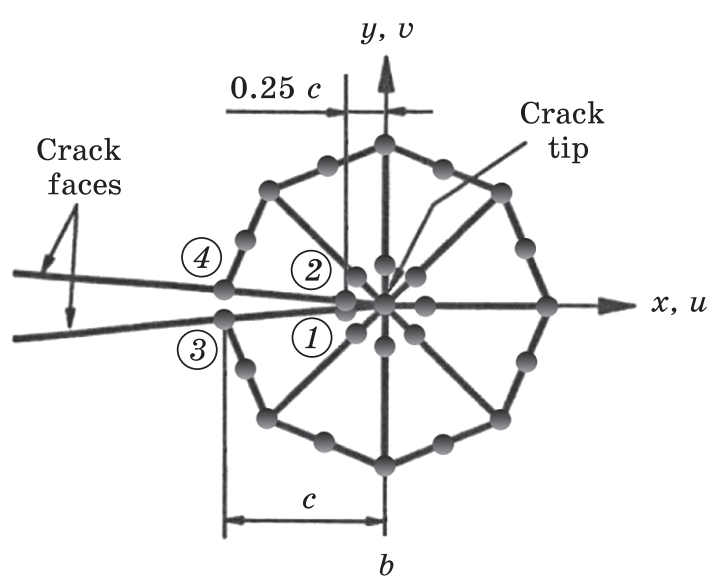

Fig. 11. Finite element model [130] of the square plate $(a)$ and the node selection scheme [131] for determining the SIF $K_{I I}$ due to the shift of the crack edges $(b)$ : 1 - the mouth of the crack, 2 - the top of the crack. Reprinted with permission from T.M. Lenkovs'kyi et al., Mater. Sci., 55, No. 4: 492 (2020). Copyright 2020, Springer [130]

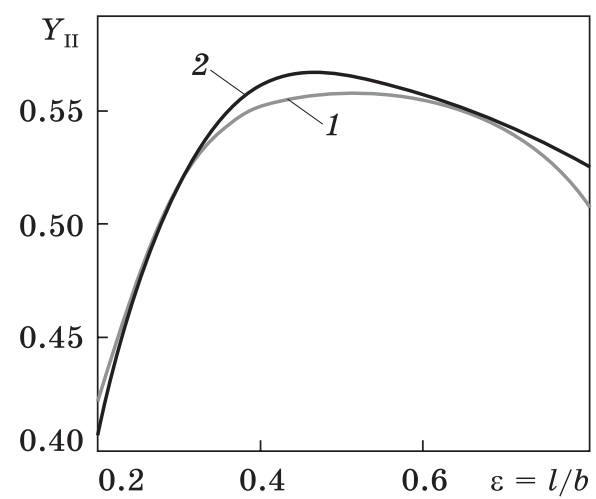

Fig. 12. K-calibration dependences for a square plate with an edge crack with a transverse shear [130], obtained taking into account the smooth contact of the crack faces: 1 - FEM; 2 - SIE. Reprinted with permission from T.M. Lenkovs'kyi et al., Mater. Sci., 55, No. 4: 492 (2020). Copyright 2020, Springer [130]

curvature of the curve obtained using the FEM method is clearer, in contrast to the curve obtained by the SIE method. This is due to the fact that the finite element model takes into account the finite size of the plate and its support on a completely rigid surface (due to the clamping of the nodes). This causes a more intense lowering of the SIF $K_{\text {II }}$ as the crack tip approaches the clamped edge of the plate.

The dependences $Y_{\text {II }}=f(1 / b)$ constructed by the SIE method taking into account $\mathrm{CFF}$ at the coefficient of friction $f_{c}=0.2 \ldots 0.6$ are similar, since with increasing coefficient $f_{c}$ the curves move along the ordinate axis towards smaller $Y_{\text {II }}$ values. Such tendencies are known [129] for other schemes of loading experimental samples. According to the results of approximation of the dependences obtained by the FEM and SIE methods, the approximate formulas for the calculation of SIF $Y_{\text {II }}$ in a square plate with an edge crack are presented (Table 6). 
Further development of the loading scheme of the sample required to determine conditions for self-similar crack propagation, which will serve as the main criterion for selecting the optimal sample sizes, during the tests of which the mechanism of quasi-brittle fracture is realized. It is well known that the conditions of self-similarity regulate the size of the crack and the body, which do not violate the specified deviation of stresses in the crack tip vicinity with finite crack dimensions (or in the small vicinity of the tip of the finite crack) in the body from stresses in the semi-infinite crack tip vicinity in the infinite body up to the edge of the fatigue process zone (plastic zone). In view of this, after performing a series of mathematical calculations [132], using the method of superposition of stress states, the conditions of self-similar crack propagation at transverse shear were determined, which limit the minimum crack length $l$ and net cross-sectional width $b-l$ of the working part of the sample. The results of the calculations were recorded as:

$$
l \geq 4\left(\frac{K_{I I}^{*}}{\tau_{0.3}}\right)^{2}, b-l \geq 7\left(\frac{K_{I I}^{*}}{\tau_{0.3}}\right)^{2} .
$$

Here $K_{\mathrm{II}}^{*}$ is the maximum SIF $K_{\mathrm{II}}$ in the load cycle during the formation of the initial macrocrack, $\tau_{0.3}$ is the conditional yield strength of the material under the shear conditions. The obtained mathematical dependences (16), which determine the relationship between the sample size and crack length, taking into account the properties of the material, will ensure the legitimacy of the use of stress criteria of linear fracture mechanics. In the study of the proposed samples, the mechanism of quasi-brittle fracture will be realized, and the determined fatigue thresholds $K_{\text {IIth }}$ will be invariant characteristics of the material under the transverse shear conditions.

\section{Conclusions}

- The analysis of existing and candidate materials for the manufacture of the gas turbine engine components has been performed and the optimal structural-phase and stress state of the materials for reliable operation has been characterized. A method of ranking these materials by fatigue thresholds at transverse shear due to the high structural sensitivity of this characteristic was proposed.

- Possible ways to increase the oxidation resistance and heat resistance of the working surfaces of metal components of the GTE, in particular, multilayer thermal barrier coatings have been analysed. Methods of their application, namely, chemical vapour deposition (CVD), physical vapour deposition (PVD), ion-plasma spraying and laser alloying were characterized. 
- The possibility of creating a holistic, scientifically sound and effective in practical use approach to determining the lifetime of metal components of the GTE was shown. Technical means to control the stress-strain state, the dynamics of microstructure degradation and changes in physical and mechanical properties of structural materials were developed.

- The importance of the engineering and technical solution proposed by us, namely, the use of modern optical-digital methods for recording the deformation of the surfaces of the GTE components to monitor their workability in the in-situ mode was substantiated. This method allows determining the critical level of damage to the local areas of the material microstructure near the stress concentrators for rapid decision-making.

- Analysis of approaches to predicting the lifetime and calculating the residual life of metal components of the engines has shown the effectiveness of the finite element method. The use of software packages allows simulating the stress-strain state of disks, turbine blades, and other components of complex geometric configuration under operating conditions.

\section{REFERENCES}

1. T. Nada, Propul. Pow. Res., 3, No. 3: 121 (2014); https://doi.org/10.1016/j.jppr.2014.07.005

2. W. Obrocki, A. Setkowicz, M. Masłyk, and J. Sieniawski, Adv. Manuf. Sci. Tech., 3, No. 2: 43 (2017);

http://advancesmst.prz.edu.pl/pdfy/10264-Volume41-Issue2-paper_04.pdf

3. W. Obrocki, A. Setkowicz, M. Masłyk, and J. Sieniawski, Adv. Manuf. Sci. Tech., 41, No. 3: 47 (2017);

http://advancesmst.prz.edu.pl/pdfy/10264-Volume41-Issue3-paper_05.pdf

4. Yu. Molkov, Ya. Ivanyts'kyi, T. Lenkovs'kyi , A. Trostianchyn, V. Kulyk, and R. Shyshkovskyy, Ukr. Jour. Mech. Eng. Mat. Sci., 5, No. 1: 39 (2019) 5/1 (2019); https://doi.org/10.23939/ujmems2019.01.039

5. S.I. Ryabtsev, V.A. Polonskyy, and O.V. Sukhova, Powder Metall. Met. Ceram., 58, Nos. 9-10: 567 (2020); https://doi.org/10.1007/s11106-020-00111-2

6. O.V. Sukhova, V.A. Polonskyy, and K.V. Ustinova, Mater. Sci., 55, No. 2: 291 (2019); https://doi.org/10.1007/s11003-019-00302-2

7. H.V. Krechkovs'ka, O.Z. Student, and H.M. Nykyforchyn, Mater. Sci., 54, No. 5: 627 (2019); https://doi.org/10.1007/s11003-019-00227-w

8. R.G. Wing, Surf. Eng. Cas., 8: 155 (1996); https://doi.org/10.1533/9780857092960.155

9. K. Peng, D. Fan, F. Yang, Q. Fu, and Y. Li, Chin. Jour. Aero., 25, No. 5: 1147 (2013); https://doi.org/10.1016/j.cja.2013.07.005

10. C. Fei and G. Bai, Mec. Sys. Sig. Proc., 49, Nos. 1-2: 196 (2014); https://doi.org/10.1016/j.ymssp.2014.04.013

11. Analysis of the Status of Flight Safety in the Civil Aviation of the Russian Federation in 2008 (Electronic resource) Access mode: http://spbguga.ru/files/Analiz_BP_2008.pdf (in Russian).

12. I. Gurrappa, J. Alloys Compd., 389, Nos. 1-2: 190 (2005); https://doi.org/10.1016/j.jallcom.2004.05.079 
13. W. Shtiller, Arrhenius Equation and Non-Equilibrium Kinetics: 100 Years, p. 176. 14. Yu.N. Nechaev, R.M. Fedorov, and L.N. Kamanin, Teoriya Aviatsionnykh Dvigatelei [Theory of Aircraft Engines] (Moscow: Voenizdat: 1980), p. 415 (in Russian).

15. L. Han, D. Huang, X. Yan, C. Chen, X. Zhang, and M. Qi, Int. Jour. Fat., 127: 120 (2019);

https://doi.org/10.1016/j.ijfatigue.2019.05.022

16. L. Witek, Fat. Air. Struct., 1, No. 4: 114 (2012);

https://doi.org/10.2478/v10164-012-0063-4

17. G.F. Harrison and W.J. Evans, J. of the Engineering Integrity Society (2000).

18. L. Witek, Eng. Fail. Anal., 13, No. 1: 9 (2006); https://doi.org/10.1016/j.engfailanal.2004.12.028

19. S.A. Meguid, P.S. Kanth, and A. Czekanski, Finite Elem. Anal. Des., 35, No. 4: 35 (2000);

https://doi.org/10.1016/S0168-874X(99)00072-4

20. R. Kumar, V. Ranjan, B. Kumar, and S.K. Ghoshal, Eng. Fail. Anal., 90: 425 (2000);

https://doi.org/10.1016/j.engfailanal.2017.12.014

21. N. E. Dowling, FFEMS, 32, No. 12 (2009);

https://doi.org/10.1111/j.1460-2695.2009.01404.x

22. J. Goodman, Mechanics Applied to Engineering (London, UK: Longmans, Green and Co.: 1919).

23. J.Morrow, Fatigue Design Handbook, Fatigue properties of metals, section 3.2, No. 4 (Warrendale, Pa, USA: Society of Automotive Engineers: 1968).

24. K. N. Smith, P. Watson, and T. H. Topper, J. of Mat., 5, No. 4: 767 (1970).

25. Z.Lv, H.Huang, and H. Gao, Jour. Mat. Sci. Tech., 29, No. 10: 4143 (2015); https://doi.org/10.1007/s12206-015-0908-1

26. K. Walker, The Effects of Stress Ratio During Crack Propagation and Fatigue for 2024-t3 and 7075-t6 Aluminum, Effect of Environment and Complex Load History on Fatigue Life, ASTM STP 462, p. 1 (American Society of Testing and Materials 1970).

27. V.N. Shlyannikov and I. S. Ishtyryakov, T. A. F. Mec., 103: 102313 (2019); https://doi.org/10.1016/j.tafmec.2019.102313

28. M. A. Miner, J. of Applied Mechanics, 12, No.3 (1945) 159-164.

29. S.P. Zhu, H.Z. Huang, and Y.F. Li, Int. Jour. of Dam. Mec., 21, No.7: 1076 (2012); https://doi.org/10.1177/1056789511432789

30. B. Salehnasab, S. Hooshmand, and A. M. Hedayat, Failure analysis of second row compressor blades, Conference: The Bi-Annual International Conference on Experimental Solid Mechanics and Dynamics (School of Mechanical Engineering, Iran University of Science and Technology, 2014);

https://www.researchgate.net/publication/259229006_Failure_analysis_of_ second_row_compressor_blades

31. P. Rygiel, W. Obrocki, and J. Sieniawski, Adv. in Man. Sci. and Tech., 41, No. 1: 43 (2017); https://doi.org/10.2478/amst-2017-0004

32. P. Govind, P. Rohit, and K. Anil, J. of Emer. Tech. Inn. Res., 3, No. 8: 18 (2016); http://www.jetir.org/papers/JETIR1608006.pdf

33. I. Shatskyi, L. Ropyak, and A. Velychkovych, Eng. Solid Mechan., 8, No. 4: 301 (2020); https://doi.org/10.5267/j.esm.2020.4.002

34. A.S.Velichkovich and T.M. Dalyak, Chem. Petrol. Eng., 51: 188 (2015); https://doi.org/10.1007/s10556-015-0022-3 
35. A. Velychkovych, I. Petryk, and L. Ropyak, Shock and Vibration, Article ID 3292713 (2020); https://doi.org/10.1155/2020/3292713

36. M.S. Leong, J. of Sys. Des. Dyn., 2, No. 1: 1 (2008); https://doi.org/10.1299/jsdd.2.24

37. A. Kermanpur, H. Sepehri Amin, S. Ziaei-Rad, N. Nourbakhshnia, and M. Mosaddeghfar, Eng. Fail. Anal., 15, No. 8: 52 (2008); https://doi.org/10.1016/j.engfailanal.2007.11.018

38. T.M. Radchenko, V.A. Tatarenko, H. Zapolsky, and D. Blavette, Journal of Alloys and Compounds, 452, No. 1: 122 (2008); https://doi.org/10.1016/j.jallcom.2006.12.149

39. L. Witek, Eng. Fail. Anal., 18, No. 4: 1223 (2011); https://doi.org/10.1016/j.engfailanal.2011.03.003

40. P. Matheron, G. Aiello, C. Caes, P. Lamagnere, A. Martin, and M. Sauzay, Nucl. Eng. Des., 284: 207 (2015); https://doi.org/10.1016/j.nucengdes.2014.12.018

41. H.R. Tahmasbi and G.R. Fayaz, Optik - Int. J. for Li. El. Opt., 126, No. 22: 3382 (2015);

https://doi.org/10.1016/j.ijleo.2015.07.002

42. H.-J. Kwon and D. Lee, Eng. Fail. Anal., 124 (2021);

https://doi.org/10.1016/j.engfailanal.2021.105386

43. M. Sujata and S. K. Bhaumik, J. of Fail. Anal. Prev., 15: 45 (2015); https://doi.org/10.1007/s11668-015-9961-4

44. E. Feulvarch, R. Lacroix, and H. Deschanels, Comp. Meth. in App. Mech. Eng., 361, No. 1 (2020); https://doi.org/10.1016/j.cma.2019.112805

45. I.P. Shatskii, Mater. Sci., 25, No. 2, 160 (1989); https://doi.org/10.1007/BF00780501

46. I.P. Shats'kyi and V.V. Perepichka, Materials Science, 40, No. 2, 240 (2004); https://doi.org/10.1007/s11003-005-0009-x

47. I.P. Shats'kyi, Mater. Sci., 41, No. 2: 186 (2005); https://doi.org/10.1007/s11003-005-0149-z

48. B. Pan, K.M. Qian, H.M. Xie, and A. Asundi, Meas. Sci. Technol., 20, No. 6: 062001 (2009).

49. Yu.V. Mol'kov, Otsiniuvannia Opirnosti Ruinuvanniu Yemnostei pid Tyskom iz Vykorystanniam Enerhetychnoho Pidkhodu [Evaluation of Pressure Vessels Fracture Resistance Using Energy Approach], Ph.D. dissertation, Karpenko Physicomechanical institute of the NAS of Ukraine, Lviv, Ukraine, 2014 (in Ukrainian).

50. T.M. Lenkovs'kyi, Yu.V. Mol'kov, M.M. Student, Kh.R. Zadorozhna, and Yu.Yu. Varyvoda, Mater. Sci., 55, No. 3: 396 (2019); https://doi.org/10.1007/s11003-019-00316-w

51. Ya.L. Ivanyts'kyi, Yu.V. Mol'kov, P.S. Kun, T.M. Lenkovs'kyi, and M. Wyjtowicz, Mater. Sci., 50, No. 4: 488 (2015; https://doi.org/10.1007/s11003-015-9746-7

52. Yu. Du, Yu.V. Mol'kov, T.M. Lenkovs'kyi, and R.A. Koval'chuk, Mater. Sci., 53, No.1: 86 (2017); https://doi.org/10.1007/s11003-017-0047-1

53. Ya.L. Ivanyts'kyi, P.S. Kun, T.M. Lenkovs'kyi, Yu.V. Mol'kov, and S.T. Shtayura, Mater. Sci., 53, No. 6: 849 (2018); https://doi.org/10.1007/s11003-018-0144-9

54. Z.A. Duriagina, Stainless Steels and Alloys (London: IntechOpen, 2019). 
55. T.M. Radchenko and V.A. Tatarenko, Defect and Diffusion Forum, 273-276: 525 (2008);

https://doi.org/10.4028/www.scientific.net/ddf.273-276.525

56. V.A. Tatarenko, S.M. Bokoch, V.M. Nadutov, T.M. Radchenko, and Y.B. Park, Defect and Diffusion Forum, 280-281: 29 (2008);

https://doi.org/10.4028/www.scientific.net/DDF.280-281.29

57. T.M. Radchenko, O.S. Gatsenko, V.V. Lizunov, and V.A. Tatarenko, Progress in Physics of Metals, 21, No. 4: 580 (2020);

https://doi.org/10.15407/ufm.21.04.580

58. A. Logunov, S. Zavodov, and D. Danilov, Mat. Tod.: Proceedings., 11, No. 1: 459 (2019);

https://doi.org/10.1016/j.matpr.2019.01.013

59. E.N. Kablov, I.L. Svetlov, and N.V. Petrushin, Nikelevyye Zharoprochnyye Splavy Dlya Lit'ya Lopatok s Napravlennoy i Monokristallicheskoy Strukturoy (Chast' 1) [Nickel Heat-Resistant Alloys for Casting Blades with Directional and Single-Crystal Structure (Part 1)] (Materialovedenie, No. 4: 32) (1997) (in Russian).

60. V.A. Tatarenko and T.M. Radchenko, Intermetallics, 11, Nos. 11-12: 1319 (2003);

https://doi.org/10.1016/S0966-9795(03)00174-2

61. Z.A. Duryagina, Physics and Chemistry of the Surface, Lviv Polytechnic National University, Lviv, 2009, p. 208 (in Ukrainian).

62. Y.-J. Yang, L.Yang, H.-K. Wang, and S.-P. Zhu, Inter. J. Turbo Jet Eng., 33, No. 4: 367 (2015); https://doi.org/10.1515/tjj-2015-0043

63. Z.A. Duriagina, R.O. Tkachenko, A.M. Trostianchyn, I.A. Lemishka, A.M. Kovalchuk, V.V. Kulyk, and T.M Kovbasyuk, J. Achievement in Mater. and Manuf. Eng., 87, No. 1: 25 (2018); https://doi.org/10.5604/01.3001.0012.0736

64. T.L. Tepla, I.V. Izonin, Z.A. Duriagina, R.O. Tkachenko, A.M. Trostianchyn, I.A. Lemishka, V.V. Kulyk, and T.M. Kovbasyuk, Archives Mater. Sci. Eng., 93, No. 1: 32 (2018); https://doi.org/10.5604/01.3001.0012.6944

65. T.Yonezawa, Comp. Nuc. Mater. (Sec. Ed.), 7: 319 (2020); https://doi.org/10.1016/B978-0-12-803581-8.00676-7

66. V.N. Bugaev, A.A. Smirnov, and V.A. Tatarenko, Int. J. Hydrogen Energy, 13, Iss. 10: 605 (1988); https://doi.org/10.1016/0360-3199(88)90009-2

67. S.H. Kim, J.-H. Cha, and C.Jang, Cor. Sci., 174 (2020); https://doi.org/10.1016/j.corsci.2020.108843

68. E.N. Kabolov, A.V. Logunov, and V.V. Sidorov, Osobennosti Legirovaniya I Termoobrabotki Litykh Zharoprochnykh Nikelevykh Splavov (Chast' 1) [Features Of Alloying And Heat Treatment Of Cast Heat-Resistant Nickel Alloys (Part 1)] (Materialovedenie, No. 4: 32 (2001) (in Russian)

69. I.M. Spiridonova, O.V. Sukhova, and A.P. Vashchenko, Metallofiz. Noveishie Tekhnol., 21, No. 2: 122 (1999) (in Russian).

70. J. Yan, Y. Gu, F. Sun, Y. Xu, Y. Yuan, J. Lu, Z. Yang, and Y. Dang, Mater. Sci. Eng. A, 675: 289 (2016);

https://doi.org/10.1016/j.msea.2016.08.085

71. O.V. Sukhova and K.V. Ustinova, Funct. Mater., 26, No. 3: 495 (2019);

https://doi.org/10.15407/fm26.03.495 
72. P. Song, M. Liu, X. Jiang, Y. Feng, J. Wu, G. Zhang, D.Wang, J.Dong, X.-Q. Chen, and L.Lou, Mater. \& Des., 197, No. 1: 109197 (2021); https://doi.org/10.1016/j.matdes.2020.109197

73. A.A. Glotka and S. V. Gaiduk, J.of App. Spect., 87, No. 21: 812 (2020); https://doi.org/10.1007/s10812-020-01075-2

74. K.L. Wang, Q.B. Zhang, M.L. Sun, X.G. Wei, and Y.M. Zhu, App. Surf. Sci., 174, No. 3-4: 191 (2001); https://doi.org/10.1016/S0169-4332(01)00017-4

75. I. Grammenos and P.T Sakiropoulos, Intermetallics, 19, No. 10: 1612 (2011); https://doi.org/10.1016/j.intermet.2011.06.008

76. Y.-J. Wang and C.-Y. Wang, Scr. Mater., 61, No. 2: 197 (2009); https://doi.org/10.1016/j.scriptamat.2009.03.042

77. V.G. Efremenko, Yu.G. Chabak, K. Shimizu, A.G. Lekatou, V.I. Zurnadzhy, A.E. Karantzalis, H. Halfa, V.A. Mazur, and B.V. Efremenko, Mater. Des., 126, 278 (2017), https://doi.org/10.1016/j.matdes.2017.04.022

78. Q.Wang, G. Cui, and H. Chen, J. Alloys Compd., 868 (2021); https://doi.org/10.1016/j.jallcom.2021.159106

79. Jeanine T. DeMasi-Marcin and Dinesh K. Gupta, Protective coatings in the gas turbine engine, Surf. Coat. Technol., 68-69: 1 (1994); https://doi.org/10.1016/0257-8972(94)90129-5

80. I. Gurrappa, Surf. Coat. Technol., 139, Nos. 2-3: 272 (2001); https://doi.org/10.1016/S0257-8972(00)01156-7

81. R. Rajendran, Eng. Fail. Anal., 26: 335 (2012); https://doi.org/10.1016/j.engfailanal.2012.07.007

82. L.S. Saakiyan, A.P. Efremov, L.Ya. Ropyak, and A.V. Gorbatskii, Soviet Materials Science, 23, No. 3: 267 (1987); https://doi.org/10.1007/BF00720884

83. L.S. Saakiyan, A.P. Efremov, and L.Ya. Ropyak, Zashchita Metallov, 25, No. 2: 185 (1989) (in Russian)

84. Q. An, J. Chen, and Z.Tao, Int. J. Refract. Met. Hard Mater., 86 (2019); https://doi.org/10.1016/j.ijrmhm.2019.105091

85. M. Aliofkhazraei and N. Ali, Comp. Mat Proc., 7: 49 (2014); https://doi.org/10.1016/B978-0-08-096532-1.00705-6

86. V. Pidkova, I. Brodnikovska, Z. Duriagina, and V. Petrovskyy, Func. Mater., 22, No. 1: 34 (2015); https://doi.org/10.15407/fm22.01.034

87. Z.A. Duryagina, S.A. Bespalov, V.Ya. Pidkova, and D.Yu. Polockyj, Metallofiz. Noveishie Tekhnol., 33, Spec. Iss.: 393 (2011).

88. A.A. Siddiqui and A.K. Dubey, Mater. Today: Proc., 44, No. 1: 1108 (2021); https://doi.org/10.1016/j.matpr.2020.11.186

89. Z. Duriagina, V. Kulyk, T. Kovbasiuk, B. Vasyliv, and A. Kostryzhev, Metals, 11, No. 3: 434 (2021); https://doi.org/10.3390/met11030434

90. M.I. Pashechko, V.V. Shyrokov, Z.A. Duryahina, and Kh.B. Vasyliv, Mater. Sci., 39, No. 1: 108 (2003); https://doi.org/10.1023/A:1026134714719

91. V.V. Shyrokov, K.B. Vasyliv, Z.A. Duryahina, H.V. Laz'ko, and N.B. Rats'ka, Mater. Sci, 45, No. 4: 473 (2009); https://doi.org/10.1007/s11003-010-9204-5

92. L.Ya. Ropyak, I.P. Shatskyi, and M.V. Makoviichuk, Metallofiz. Noveishie Tekhnol., 41, No.5: 647 (2019); 
https://doi.org/10.15407/mfint.41.05.0647

93.Z.A. Duryagina, S.A. Bespalov, A.K. Borysyuk, and V.Ya. Pidkova, Metallofiz. Noveishie Tekhnol., 33, No. 5: 615 (2011).

94.R.M. Tatsiy, O.Y. Pazen, S.Y. Vovk, L.Y. Ropyak, and T.O. Pryhorovska, J. of Serb. Soc. Comp. Mech., 13, No. 2: 36 (2019); https://doi.org/10.24874/JSSCM.2019.13.02.04

95.V.M. Posuvailo, V.V. Kulyk, Z.A. Duriagina, I.V. Koval'chuck, M.M. Student, and B.D. Vasyliv, Archives of Mater. Sci. and Eng., 105, No. 2: 49 (2020); https://doi.org/10.5604/01.3001.0014.5761

96.L.Ya. Ropyak, I.P. Shatskyi, and M.V. Makoviichuk, Metallofiz. Noveishie Tekhnol., 39, No. 4: 517 (2017);

https://doi.org/10.15407/mfint.39.04.0517

97.Z.A. Duryahina, T.M. Kovbasyuk, S.A. Bespalov, and V.Y. Pidkova, Mater. Sci., 52, No. 1: 50 (2016);

https://doi.org/10.1007/s11003-016-9925-1

98.I.P. Shatskyi, L.Ya. Ropyak, and M.V. Makoviichuk, Strength of Materials, 48 , No. 5: 726 (2016);

https://doi.org/10.1007/s11223-016-9817-5

99.I.P. Shatskyi, V.V. Perepichka, and L.Ya. Ropyak, Metallofizika i Noveishie Tekhnologii, 42, No. 1: 69 (2020); https://doi.org/10.15407/mfint.42.01.0069

100. O. Ivanov, P. Prysyazhnyuk, D. Lutsak, O. Matviienkiv, and V. Aulin, Management Systems in Production Engineering, 28, No. 3: 178 (2020); https://doi.org/10.2478/mspe-2020-0026

101. M. Hetmanczyk, L. Swadzba, and B. Mendala, J. of Ach. Mater. Manuf. Engin., 24, No.1: 372 (2007);

https://www.researchgate.net/publication/40804836_Advanced_materials_ and_protective_coatings_in_aero-engines_application

102. X. Cao, Development Of New Thermal Barrier Coating Material For Gas Turbines, Berichte des forschungszentrums julich (PhD thesis ISSN 0944-2942) (Denmark: 2004).

103.S. Paul, Pore Architecture in Ceramic Thermal Barrier Coatings (PhD thesis) (UK: Cambridge University: 2007).

104. S. Tsipas, Thermophysical Properties of Plasma Sprayed Thermal Barrier Coatings (PhD thesis) (UK: Cambridge University: 2005).

105. R. Rajendran, V. Raja, R. Sivakumar, and R. Srinivasa, Surf. Coat. Technol., 73, No.3: 198 (1995); https://doi.org/10.1016/0257-8972(94)02368-9

106. Y. Cao, X. Ning, and Q. Wang, Surf. Coat. Technol., 409 (2021); https://doi.org/10.1016/j.surfcoat.2021.126842

107. O.M. Romaniv and B.D. Vasyliv, Mater. Sci., 34, No. 2: 149 (1998); https://doi.org/10.1007/BF02355530

108. O.M. Romaniv and B.D. Vasyliv, Mater. Sci., 31, No. 6: 750 (1996); https://doi.org/10.1007/BF00558596

109. A.D. Ivasyshyn and B.D. Vasyliv, Mater. Sci., 37, No. 6: 1002 (2001); https://doi.org/10.1023/A:1015669913601

110. O.M. Romaniv, I.V. Zalite, V.M Simin'kovych, O.N. Tkach, and B.D. Vasyliv, Mater. Sci., 31, No. 5: 588 (1996);

https://doi.org/10.1007/BF00558793

111. Yu.G. Chabak, V.I. Fedun, T.V. Pastukhova, V.I. Zurnadzhi, V.G. Efremenko, and S.P. Berezhnyj, Prob. of Atomic Sceince and Technology, 110, No. 4: 97 (2017); https://vant.kipt.kharkov.ua/ARTICLE/VANT_2017_4/article_2017_4_97.pdf 
112. W. Fan, Y. Bai, Y.F. Liu, Y.X. Kang, Y. Wang, Z.Z. Wang, and W.Z. Tao, Ceram. Int., 12, No. 5: 15763 (2019);

https://doi.org/10.1016/j.ceramint.2019.05.063

113. O.Z. Student, H.V. Krechkovska, H.M. Nykyforchyn, and O.I. Zvirko, The Operated Steel Degradation Peculiarities Of The Different Elements Of Power Steam Pipelines (14th International Conference on Fracture: 2017), p. 249.

114.H.V. Krechkovs'ka , Mater. Sci., 51, No. 4: 509 (2016); https://doi.org/10.1007/s11003-016-9869-5

115. L. Swadzba, B. Formanek, H.M. Gabriel, P. Liberski, and P. Podolski, Surf. Coat. Technol., 62, Nos. 1-3: 486 (1993); https://doi.org/10.1016/0257-8972(93)90288-Y

116. K. Bobzin, T. Brogelmann, and C. Kalscheuer, Surf. Coat. Technol, 38 (2020); https://doi.org/10.1016/j.surfcoat.2019.125046

117. V.G. Efremenko, Yu.G. Chabak, A. Lekatou, A.E. Karantzalis, K. Shimizu, V.I. Fedun, A.Yu. Azarkhov, and A.V. Efremenk, Surf. Coat. Technol., 304 (2016);

https://doi.org/10.1016/j.surfcoat.2016.07.016

118. M.Z.B. Abdullah, A.N.B. Abdullah, M.H.B. Othman, M.A.B. Ahmad, and P. Hussain, Mater. Tod.: Proceed., 16, No. 4: 2067 (2019);

https://doi.org/10.1016/j.matpr.2019.06.093

119. P. Prysyazhnyuk, D. Lutsak, L. Shlapak, V. Aulin, L. Lutsak, L. Borushchak, and T.A. Shihab, Eastern-European Journal of Enterprise Technologies, 6, Nos. 12-96: 43 (2018);

https://doi.org/10.15587/1729-4061.2018.150807

120. N.G. Shul'zhenko, P.P. Gontarovskii, and I. I. Melezhik, Str. Mater., 40, No. 5: 566 (2008); https://doi.org/10.1007/s11223-008-9069-0

121. T.M. Lenkovs'kyi, Mater. Sci., 53, No. 2: 200 (2017); https://doi.org/10.1007/s11003-017-0063-1

122. G. Lesiuk, M. Smolnicki, D. Rozumek, H. Krechkovska, O. Student, J. Correia, R. Mech, and A. De Jesus, Materials, 13, No. 1: 160 (2020); https://doi.org/10.3390/ma13010160

123. O.P Ostash, V.V. Kulyk, T.M. Lenkovskiy, Z.A. Duriagina, V.V. Vira, and T.L. Tepla, Archives of Mater. Sci. and Eng., 90, No. 2: 49 (2018);

https://doi.org/10.5604/01.3001.0012.0662

124. T.M. Lenkovskiy, V.V. Kulyk, Z.A. Duriagina, R.A. Kovalchuk, V.H. Topilnytskyy, V.V. Vira, and T.L. Tepla, Archives of Mater. Sci. and Eng., 84, No. 1: 34 (2017); https://doi.org/10.5604/01.3001.0010.3029

125. V.V.Kulyk, T.M. Lenkovs'kyi, and O.P. Ostash, Strength Mater., 49, No. 2: 256 (2017); https://doi.org/10.1007/s11223-017-9865-5

126. T.M. Lenkovs'kyi, Mater. Sci., 50, No. 3: 340 (2014); https://doi.org/10.1007/s11003-014-9725-4

127.DSTU 8601:2015. Strength Analyses and Tests, A Method for the Determination of the Characteristics of Cyclic Crack Resistance of Metals under Transverse Shear and at Room Temperature (Valid since 01.01.2017) (in Ukrainian)

128. O.P. Datsyshyn and V.V. Panasyuk, Mater. Sci., 52, No. 4: 447 (2017); https://doi.org/10.1007/s11003-017-9977-x

129. Y.L. Ivanytskyj, T.M. Lenkovskiy, Y.V. Molkov, V.V. Kulyk, and Z.A. Duriagina, Archives of Mater. Sci. and Eng., 82, No. 2: 49 (2016);

https://doi.org/10.5604/01.3001.0009.7103 
130. O.P. Datsyshyn, T.M. Lenkovskyi, and A.Yu. Glazov, Mater. Sci, 55, No. 4: 492 (2020); https://doi.org/10.1007/s11003-020-00330-3

131.T.M. Lenkovskiy, V.V. Kulyk, Z.A. Duriagina, R.A. Kovalchuk, V.G. Topilnytskyy, V.V. Vira, T.L. Tepla, O.V. Bilash, and K.I. Lishchynska, Archives of Mater. Sci. and Eng., 87, No.2: 56 (2017); https://doi.org/10.5604/01.3001.0010.7446

132. T.M. Lenkovs'kyi, P.S. Kun', W. Dudda, and E.V. Kharchenko, Mater. Sci., 54, No. 3: 361 (2018);

https://doi.org/10.1007/s11003-018-0193-0

Received 14.06.2021; in final version, 15.11.2021

3.А. Дурягіна ${ }^{1,2}$, В.В. Кулик ${ }^{1}$, О.С. Філілонов ${ }^{1}$, А.М. Тростянчин ${ }^{1}$, Н.Б. Сокульська ${ }^{3}$

${ }^{1}$ Національний університет «Львівська політехніка», вул. Степана Бандери, 12, 79013 Львів, Україна

2 Люблінський католицький університет Яна Павла II, Ал. Рацлавіцкє 14, 20950 Люблін, Польща

${ }^{3}$ Національна академія сухопутних військ імені гетьмана Петра Сагайдачного, вул. Героїв Майдану, 32, 79012 Львів, Україна

РОЛЬ НАПРУЖЕНО-ДЕФОРМОВАНОГО СТАНУ

МЕТАЛЕВИХ ДЕТАЛІВ ГАЗОТУРБІННИХ ДВИГУНІВ

У ПРОГНОЗУВАННІ ЇХНЬОГО БЕЗПЕЧНОГО РЕСУРСУ

Проаналізовано та систематизовано вплив різних чинників на роботоздатність металевих деталів газотурбінних двигунів (ГТД). Показано, що лопатки компресора виходять з ладу в результаті пошкоджень сторонніми предметами, газової корозії й ерозії. Хвостовики лопаток компресора частіше руйнуються від фретингового зношування під дією вібрацій, в той час як ялинкоподібні виступи дисків турбін зазнають ушкоджень за малоциклової втоми (LCF) та плазучости. Збільшення радіальних зазорів між ротором і статором турбіни понижує силу тяги та змінюе газодинамічні навантаження на елементи двигуна. Додаткове окиснення металевих деталів спостерігається під впливом гарячих газів у камері згоряння. Описано принципи вибору матеріалів для виготовлення лопаток і дисків турбін, концепції легування жароміцних стопів, сучасні методи інженерії поверхні для нанесення захисних жаротривких покриттів, зокрема, хімічне осадження з парової фази (CDV), фізичне осадження з парової фази (PVD), повітряноплазмове напорошення (APS) тощо. Для прогнозування довговічности дисків турбін запропоновано використовувати модифіковану Уокерову модель і Майнерове правило, а метод скінченних елементів - для встановлення часу до руйнування металевих лопаток турбін. Для моніторингу деформацій робочих поверхонь ГТД рекомендовано використовувати оптико-цифрові методи.

Ключові слова: матеріали газових турбін, втома, довговічність, пошкоджуваність, захисні покриття, метод скінченних елементів. 